\title{
Biology and Properties of Fish and Reptilian Herpesviruses
}

\author{
KEN WOLF
}

\section{INTRODUCTION}

This chapter updates and adds to information contained in earlier reviews of herpesvirus of reptiles and fishes (Wolf, 1973, 1979; Lunger and Clark, 1978; Clark and Lunger, 1981). This review includes at least 11, and possibly as many as 14 , herpesviruses (Table I). The uncertainty of number stems from the fact that some of the agents have yet to be isolated, and therefore their antigenic, serological, and other critical relationships are unknown. Furthermore, the rather high degree of host specificity exhibited by most herpesviruses suggests the possibility that the two freshwater turtles (both family Testudinidae) could well be afflicted with a single virus. The same is true for the agent(s) seen in the venom of the three snakes of the family Elapidae; two of the snakes are members of the genus Naja, and all three share a common geographic area.

One generalization to be drawn from the collected reports is that in certain of their biological and biophysical properties, the herpesviruses of lower vertebrates share common characteristics. As an example, the representatives of poikilotherm vertebrate agents have temperature optima and ranges that conform to the preferred temperature or near-optimal environmental temperatures of their hosts.

Herpesvirus-host relationships of the fish and reptile agents also conform to patterns recognized among the herpesviruses of homeotherms. The channel catfish virus, Herpesvirus salmonis, and Oncorhynchus masou virus are agents of virulent disease and result in mortality of young

KEN WOLF - National Fish Health Research Laboratory, U.S. Fish and Wildlife Service, Kearneysville, West Virginia 25430. 


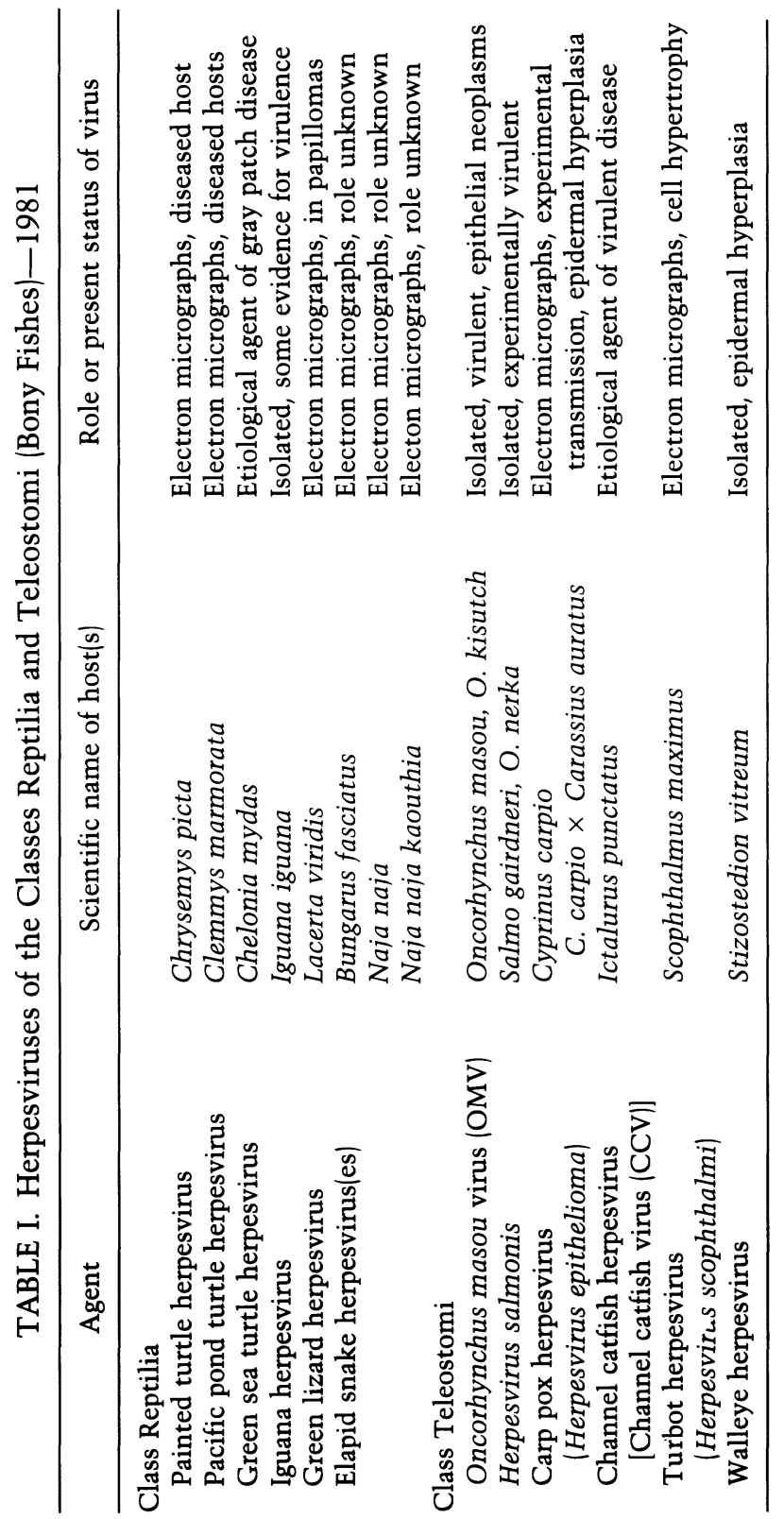


hosts. Although the story of salmonid herpesviruses is fragmentary, it is known that adult fish harbor the viruses, and that feature ensures generation-to-generation transmission or continuity of the pathogen. The gray patch disease of green sea turtles similarly fits the group of agents that are virulent for the young but incapable of evoking disease in older animals. Moreover, the skin, which is the target tissue of the gray patch agent, is similarly afflicted in other herpesvirus infections.

In some instances, neoplasms result from homeotherm herpesvirus infections. The agents associated with carp pox, walleye epidermal hyperplasia, and possibly the green iguana infection plausibly seem to play a causal role in neoplasia. It would not be surprising to find that these three viruses are highly virulent for the very young and that neoplasms are sequelae that occur only among some survivors.

Virulence for young hosts and neoplasm induction among survivors focus attention on a common research need in working with animals other than so-called domestic species and the need for young specificpathogen-free animals for experimental infections. Some hatchery populations of fishes-notably some species of trout-have health histories that document freedom from specific pathogens; therefore, suitable test trout are available for research. At the other extreme, herpesviruses occur in such feral animals as turbot, iguanas, and cobras. How or where, for example, does one obtain young cobras, or more specifically, young cobras that do not harbor latent or interfering virus?

Just as most of the herpesviruses of homeotherms come from domesticated birds and mammals rather than from feral species, the herpesviruses of reptiles and fishes come from zoo specimens or from species under aquaculture. The agents themselves, like their hosts, originated in the wild but were recognized and came under scrutiny among animals in captivity-especially when they caused disease and mortality.

Knotty problems exist among the poikilotherm vertebrate viruses; several have yet to be isolated, e.g., carp pox agent and agent/s) from elapid snakes. The easiest to solve undoubtedly is the problem of cell toxicity of venom in which snake herpesvirus is found. Conceivably, one could infect embryonate snake eggs or hatchlings, produce a systemic infection, and derive a virus suspension free of lytic venom. In the two agents yet to be isolated from adult fishes, culture of neural tissue has not been reported for the channel catfish virus. The role of carp pox agent in young fish has yet to be determined; if it proves to be virulent, isolation of the virus from the young might be simple. Alternatively, and in either case, the virus may respond to temperature manipulation, as does the agent of Lucké adenocarcinoma of frogs.

Among viruses that have been isolated, those of fish and reptiles induce syncytia in susceptible cell cultures. Generally, too, the infected cells show basophilia, margination of chromatin, and intranuclear inclusions-all characteristics of homeotherm herpesviruses.

In this review, the word fish is used in the restricted sense and means 
only that class of vertebrates known as teleosts, or bony fishes. Still lower classes of vertebrates, loosely termed fishes, have yet to yield evidence of herpesvirus infections: class Chondrichthyes (sharks, skates, and rays) and class Agnatha (lampreys and hagfishes). Because herpesvirus has been visualized in mollusks, it is reasonable to expect that additional agents will eventually be found in animals such as sharks or lampreys. The search for such agents is now handicapped by the fact that cell lines have yet to be developed from either Chondrichthyes or Agnatha (Wolf and Mann, 1980).

Some of the original literature on the agents covered in this review contains qualifying terms such as herpeslike or herpesviruslike, but for convenience and simplicity, all are referred to here as herpesvirus.

\section{REPTILIAN HERPESVIRUSES}

\section{A. Painted Turtle Herpesvirus}

The painted turtle (Chrysemys picta) is a common chelonian member of the family Testudinidae; it is found in North American freshwater habitats from the Atlantic coast to eastern Washington State. A herpesvirus has been seen in affected tissues of a diseased adult male specimen from the Toronto, Ontario, Zoo (Cox et al., 1980). Presumably, the turtle came from the local area.

The turtle had an abscessed swelling on the side of its head. After surgical excision, the site was topically disinfected with an iodophore and the animal injected with chloramphenicol and ascorbic acid. Nevertheless, the animal died 6 days later and was necropsied the same day. Gross findings included pulmonary edema, a friable and discolored liver, congested spleen, pale kidneys, and necrotic lesions on the plastron. Liver, lung, intestine, spleen, and kidney tissues were fixed for histopathological examination and electron microscopy.

Major pathological changes were found in the liver and lung. Many small foci of coagulation necrosis were present in the liver. The inflammatory response was minor, but nearby hepatocytes contained large eosinophilic intranuclear inclusions, and the nuclei additionally had marginated chromatin (Fig. 1). Bronchi showed accumulations of mononuclear and granulocytic cells, the latter often invading the mucosa. Lumens were usually filled with granulocytes, erythrocytes, and sloughed epithelial cells. Epithelial cells of the infundibula were metaplastic, vacuolated, and degenerate. Many cells displayed eosinophilic intranuclear inclusions (Fig. 2). Accumulations of inclusion-bearing epithelial cells, granulocytes, and fibrin were present in pulmonary infundibula. Occasional degenerated renal tubules contained mineralized debris, and small focal accumulations of granulocytes and mononuclear cells were present in interstitial tissue. Renal pathology, however, was judged to have resulted from inadequate water intake. 


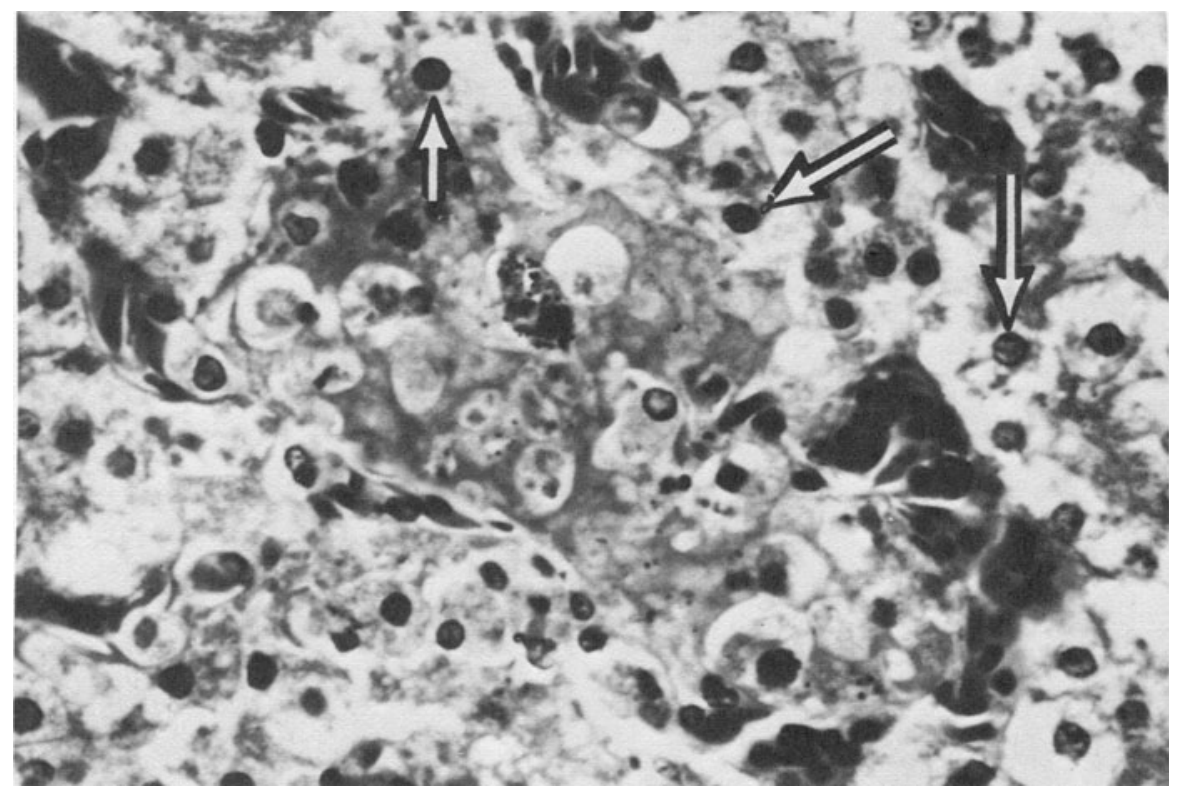

FIGURE 1. Necrotic focus in liver of painted turtle. Nearby hepatocytes contain dense intranuclear inclusions (arrows). Hematoxylin-eosin. $\times 560$. From Cox et al. (1980). Reprinted with the permission for the Wildlife Disease Association.

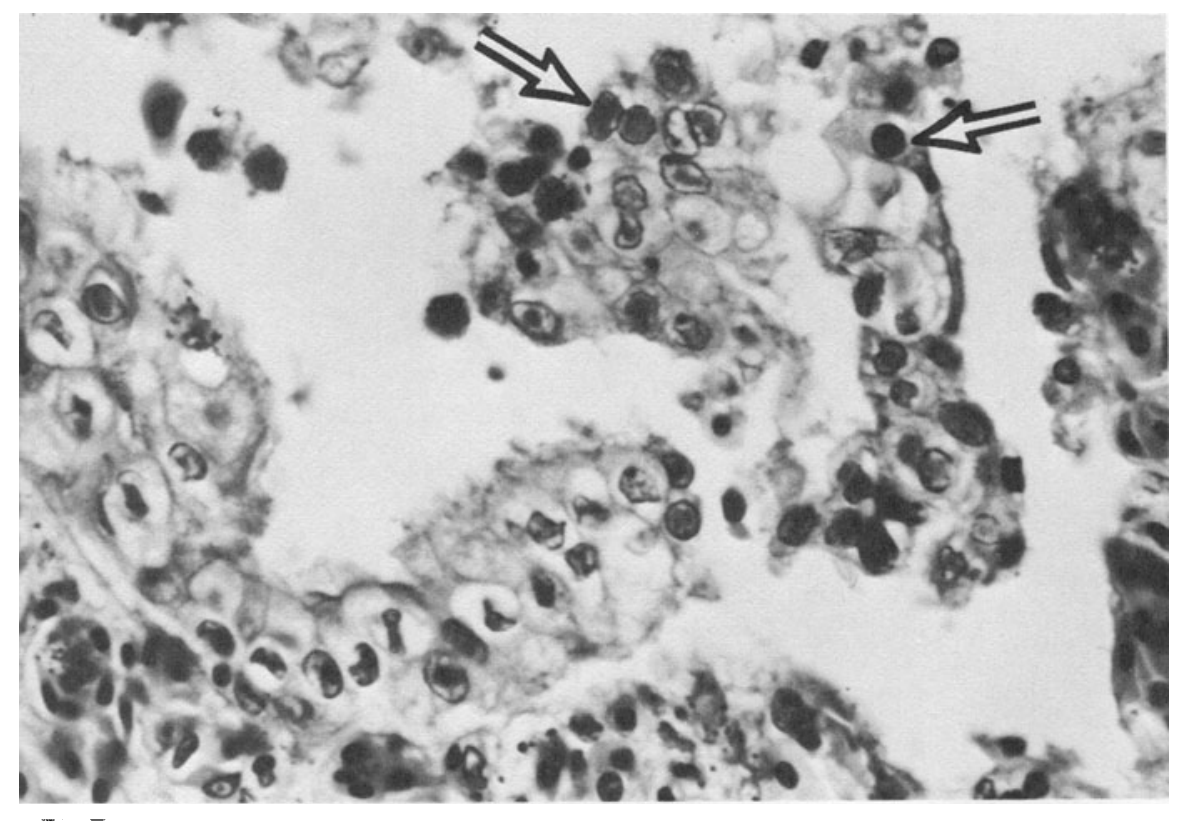

FIGURE 2. Section of painted turtle lung showing lumen with sloughed epithelial cells some of which have prominent intranuclear inclusions (arrows). Hemotoxylin-eosin. $\times 560$. From Cox et al. (1980). Reprinted with the permission of the Wildlife Disease Association. 
Evidence of the herpesvirus was obtained by electron microscopy. Hepatocytes and bronchial epithelial cells both showed numerous virions in cell nuclei (Fig. 3). Most of the particles were naked capsids measuring 85-115 nm, but some enveloped virions were also evident.

The authors noted that only fixed material was available, and accordingly neither animal inoculation nor isolation attempts could be carried out. They noted further, however, that the disease of the painted turtle resembled that of the Pacific pond turtle described by Frye et al. (1977).

\section{B. Pacific Pond Turtle Herpesvirus}

The Pacific pond turtle (Clemmys marmorata) is a common chelonian member of the family Testudinidae; it occupies fresh water and at

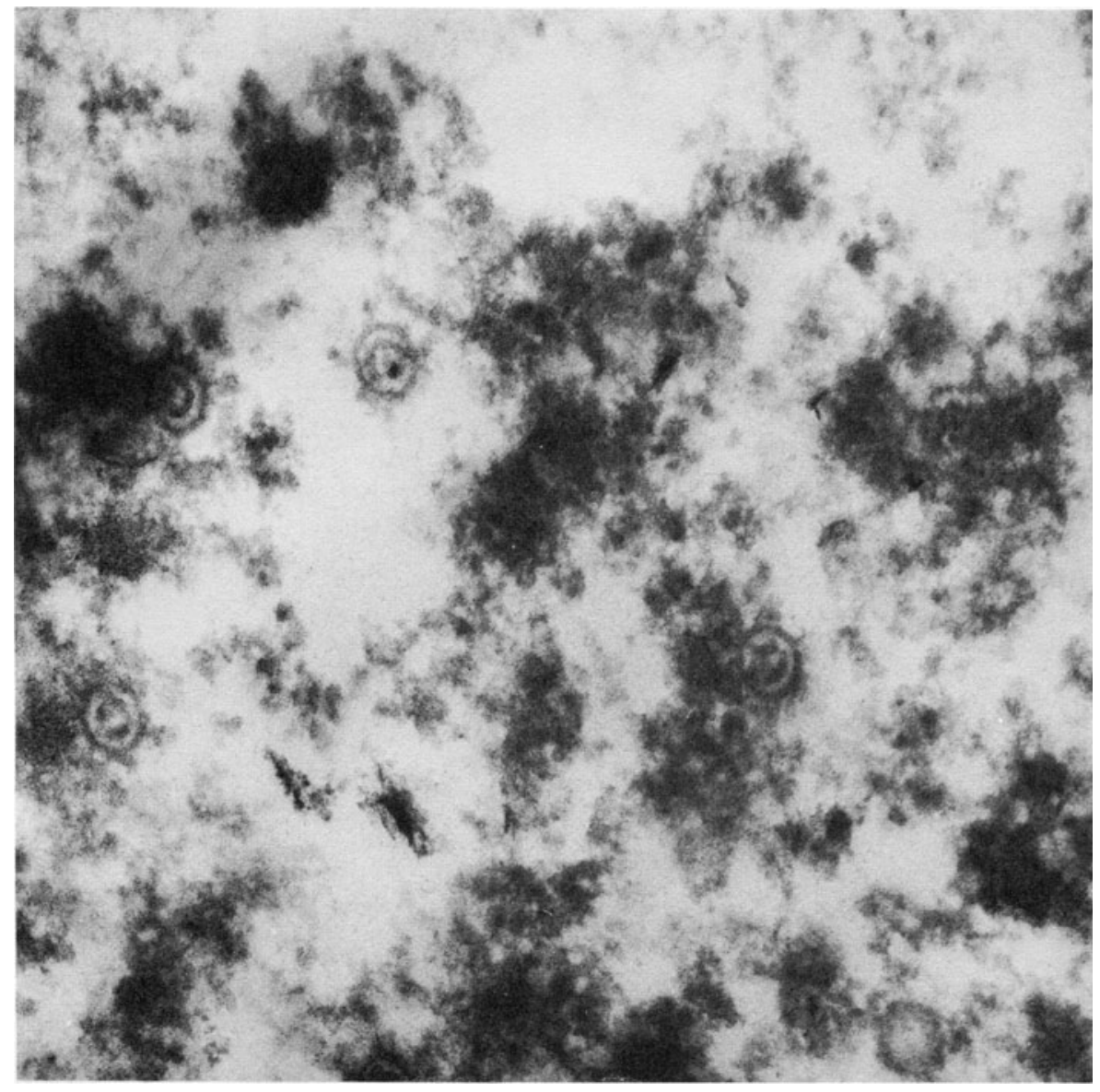

FIGURE 3. Herpesvirus particles in thin section of hepatocyte from a painted turtle. $\times 18,400$. From Cox et al. (1980). Reprinted with the permission of the Wildlife Disease Association. 
times brackish waters along the Pacific slope of the United States from San Diego to Puget Sound. Herpesvirus was seen in tissue sections of a diseased adult specimen that was necropsied after death (Frye et al., 1977).

The case involved two wild specimens. The first was an adult female submitted for examination in a lethargic and anorexic condition and showing muscular weakness and feeble response to tactile stimulation. The skin of the neck and limbs, and the plastron, bore numerous petechiae and small ecchymotic hemorrhages. The turtle died within a few hours after admission.

Several weeks later, the owner submitted a companion adult male with identical signs, which also died shortly after admission. An acute or peracute disease course was indicated. Radiological, hematological, and histopathological examinations were carried out. Radiological examination showed no abnormalities, but blood films showed moderate lymphocytosis, a reduced eosinophil count, and vacuolated erythrocytes.

Internally, the liver and spleen of both turtles were slightly swollen; the kidneys were pale, but other organs appeared to be normal. Histological sections stained with hematoxylin and eosin showed acute hepatic necrosis. Many of the hepatocytes and some spleen and renal-tubule cells showed intranuclear inclusions and margination of chromatin. Small lymphocytes occurred in aggregates in liver, kidneys, and spleen, and the spleen was moderately hyperplastic.

Electron microscopy of thin sections of liver and spleen showed intranuclear icosahedra $100 \mathrm{~nm}$ in diameter. Some capsids were empty, but others bore electron-dense nucleoids. Enveloped particles (140 nm) occurred both extracellularly and in the cytoplasm. Bundles of dense fibers were present extracellularly in the cytoplasm and occasionally in cell nuclei. Although the point was not discussed by the authors, their micrograph of an intranuclear bundle resembled material found in cells infected with channel catfish virus or Herpesvirus salmonis.

The occurrence of similar disease signs and associated herpesvirus in two different freshwater turtles in the same family logically leads one to ask whether a single virus was involved. An opposing viewpoint is tenable, however, because the natural ranges of the two turtles do not overlap. One must then counter with questions regarding natural hostpathogen relationships and species composition of turtle populations kept in zoos or other captivity.

These matters may be clarified when new cases are brought to light, viral isolations are made, and definitive serological tests are carried out.

\section{Green Sea Turtle Herpesvirus (Gray Patch Disease)}

The green sea turtle (Chelonia mydas) is a large marine reptile native to the Americas and a member of the family Chelonidae. Its range extends along the Atlantic from New England to northern South America and in Pacific waters from southern California through Lower California. Che- 
lonia mydas is one of the few turtles raised commercially for human food.

Herpesvirus involvement in what is termed gray patch disease first came to light with the report of Rebell et al. (1975), who described recurrent epizootics among hatchlings under intensive aquaculture at a commercial facility in the British West Indies. Each of nine successive hatches of young turtles underwent outbreaks of skin lesions involving $90-100 \%$ of the respective populations, and mortality of $5-20 \%$ was associated with the condition.

Other than the skin lesions from which the disease takes its name, it is difficult to define precisely the limits of the infection. With little doubt, the herpesvirus infection, or gray patch disease, is age-dependent and is very probably influenced by crowding, handling, organic pollution, fluctuating temperature, and hygiene-factors inherent in the commercial venture (Haines, 1978).

The virus is most virulent among animals 2-6 weeks old. Young victims do not develop skin lesions, possibly because the incubation period is so short. The sole finding is impaction of feces in the lower digestive tract. Under husbandry, mortality in this youngest age group may reach $20 \%$, but experimental infections lead to $100 \%$ mortality, without skin lesions but again with impacted feces. Behavior changes were not mentioned.

Clinically obvious gray patch disease typically occurs when turtles are 2-4 months old. The condition occurs as either of two kinds of skin lesions. The lesser lesions are benign, sharply circumscribed, nonspreading papules on the neck and flippers; they eventually regress. The more severe lesions consist of spreading gray patches with superficial epidermal necrosis. Gray patches enlarge at a rate of about $5 \mathrm{~mm}$ per week; when most severe, the entire epidermis may be affected and the animals die (Haines, 1978). Elevated temperatures (about $30^{\circ} \mathrm{C}$ ) seem to exacerbate the disease; mortality is higher in summer than in winter.

After the turtles reach 1 year of age, they no longer contract gray patch disease, nor can the condition be induced experimentally. Haines (1978) postulated that the animals, presumably survivors of earlier epizootics, have become immune. It would be interesting to determine whether previously unexposed yearlings are similarly resistant.

Histologically, the papules are small and sharply defined and show marked epidermal hyperkeratosis and acanthosis. The upper epidermal layers have slighlty basophilic nuclear inclusions surrounded by a clear halo, and chromatin is clumped at the periphery of the inclusions. The upper epidermis is infiltrated by eosinophils and the dermis by eosinophils and mononucleated cells.

The histopathological picture of spreading lesions is similar to that of papules, but more extensive. Keratosis is marked, and deeper layers of keratin show residual nuclei with inclusions and clumps of invading gram-negative rods. The upper keratin layer shows gram-positive cocci. 
Epidermis beneath the keratin is acanthotic, and hyperplastic tissue is papillomatous. Eosinophils infiltrate the junction of keratin with epidermis. Late stages of the lesion show replacement of the epidermis by a necrotic crust, fibrin, and inflammatory cells. Neither polykaryocytes nor syncytia are mentioned.

Biopsies and skin scrapings examined by electron microscopy show abundant enveloped viral particles that measure 160-180 nm. Capsids measure 105-120 nm.

Experimental transmission was first effected by scratching flippers of 6- to 8-week-old hatchlings and inoculating the scratch lines with lesion material. Clinical signs appeared in 2-3 weeks among all those inoculated, and histology and electron microscopy confirmed the presence of virus (Rebell et al., 1975). According to Haines (1978), turtles that are 2-4 months old can be experimentally infected by the scratch method. Clinical gray patch develops, but the animals recover.

Haines and Kleese (1977) investigated the effects of controlled temperature on the course of gray patch disease arising spontaneously among 3-week-old hatchlings under conditions that obviated other stress factors. Work was carried out at a location remote from the aquaculture facility. Experimental animals were free of gray patch disease at the start of the study, and the authors made a point of noting that hatchlings were from eggs that had been taken in the wild. Four different temperature regimens were used, and naturally occurring gray patch disease broke out among all groups. Controls held at constant $25^{\circ} \mathrm{C}$ first showed clinical signs at day 20 , and the condition reached a peak incidence of about $90 \%$ at 32 days. The group subjected to a gradual temperature elevation to $30^{\circ} \mathrm{C}$ and then a reduction to $25^{\circ} \mathrm{C}$ had an incubation time of only 8 days; among them, the rate of disease increase was greater than that in controls, but at day 32 the final percentage was about the same. Temperature effects were most pronounced among the groups that were raised from 25 to $30^{\circ} \mathrm{C}$ and either held there or abruptly moved to $30^{\circ} \mathrm{C}$ for 4 days and then returned to $25^{\circ} \mathrm{C}$. Turtles at constant $30^{\circ} \mathrm{C}$ showed an 8 -day incubation time, but the incidence increased much more rapidly than in the controls; however, the final percentage was similar. Incubation was shortest-only 2 days-in animals subjected to sudden transfer to $30^{\circ} \mathrm{C}$, then held there 4 days and returned to $25^{\circ} \mathrm{C}$. The rate of disease appearance was the most rapid and the final incidence was highest, about $96 \%$.

Severity of lesions was graded; the most severe disease occurred among turtles held at constant $30^{\circ} \mathrm{C}$ or subjected to sudden temperature changes. The trials were held over a period of 7 weeks, and it is worth noting that under near-ideal conditions, gray patch disease disappeared spontaneously 4-6 weeks after the trials were terminated.

Haines (1978) postulated that reduction of temperature may be one means of lowering mortality and morbidity from gray patch disease. One could add that mitigation of stress factors could also have a favorable effect. Haines (1978) also reported that successful vaccination was 
achieved. Virus was recovered from gray patch lesions, partly purified, inactivated, and injected intramuscularly into young turtles. Hatchlings so immunized proved to be protected against active virus administered by scratch inoculation.

Considerable effort has been spent in attempts to isolate the gray patch agent. Haines (1978) mentioned that mammalian, fish, and reptilian cell lines were tried, but that the only cells to show consistent cytopathic effects were derived from green sea turtle skin. Culture-grown virus was infective for turtles that were inoculated by the scratch method. Koment and Haines (1977) found that the virus replicated rapidly at $25^{\circ} \mathrm{C}$ and that it was distinguishable from channel catfish virus and herpes simplex; they found also that its effects in vitro were charactertistic of herpesviruses.

Circumstantial evidence suggests that the gray patch agent is carried by survivors that reach sexual maturity. Rebell et al. (1975) commented briefly on the "prevalence of skin lesions in turtles of all ages" (italics added). Perhaps skin lesions that persist in the adult harbor the virus and provide generation-to-generation transmission. One wonders, too, whether virus is transmitted vertically, perhaps infecting some embryos in ovo. However the virus is harbored or carried, the general pattern of virulence for the young and development of resistance with age is similar to that of channel catfish virus and the salmon herpesvirus Oncorhynchus masou virus.

\section{Iguana Herpesvirus}

The green iguana (Iguana iguana) is a New World herbivorous and terrestrial lizard of the family Iguanidae.

As part of a program of developing reptilian cell lines for virological application, Clark and Karzon (1972) prepared primary cultures from several tissues of an apparently normal adult male green iguana from a community lizard and turtle cage at the Buffalo, New York, Zoo. Cultures were incubated at 23 or $30^{\circ} \mathrm{C}$, but cell outgrowth occurred only at $30^{\circ} \mathrm{C}$, beginning within $2-10$ days. From the 13th to the 30th day, syncytia became evident sequentially in cultures of liver, spleen, kidney, and heart; that development was followed by lysis and cell death. When infective culture fluid was inoculated onto the TH-1 cell line of box turtle (Terrapene carolina) heart origin, syncytia were induced. Similar primary cultures were prepared from kidney and lung tissues of a second adult male iguana from the same community cage; they too developed syncytia and degenerated. Although other tissues were cultured, viral effects did not become evident; in fact, heart tissues gave rise to the permanent iguana cell line IgH2, which subsequently proved susceptible to the iguana virus. In their efforts to detect virus by natural transmission, Clark and Karzon (1972) held an immature green iguana in the zoo's community 
cage for 2 months, but viral infection could not be demonstrated in the animal.

In vitro, the iguana virus grows at $23-36^{\circ} \mathrm{C}$, but optimal temperature is $30^{\circ} \mathrm{C}$. Syncytia are produced at $36^{\circ} \mathrm{C}$, but no virus is released. Maximal titer at $23-30^{\circ} \mathrm{C}$ is about $10^{7}$ plaque-forming units $/ \mathrm{ml}$; most infectivity is cell-associated, only $1 \%$ being released. The virus is ether-sensitive, inhibited by 5-bromodeoxyuridine, and substantially retained on filter membranes of $220-\mathrm{nm}$ mean porosity. Thermal-inactivation data for virus in culture medium with $10 \%$ serum shows stability at $4^{\circ} \mathrm{C}$ (and presumably at lower temperatures as well) and one-hit kinetics; at $37^{\circ} \mathrm{C}$, the halflife is about $13 \mathrm{hr}$. The virus is replicated by several cell lines of iguana origin, as well as by several lines from the box turtle. Syncytia, but otherwise nontransferable cytopathic effect $(\mathrm{CPE})$, were produced in cell lines from other reptiles, the gekko, caiman, and python. No CPE occurred in cell lines from the sidenecked turtle, Russell's viper, fish, amphibian, chick embryo, or mammals. In all, 13 different vertebrate cell cultures or lines proved to be completely refractory.

In addition to syncytia, susceptible cell cultures showed prominent eosinophilic intranuclear inclusions and margination of chromatin.

Representative vertebrates of several classes were inoculated with iguana virus, but the agent was recovered only from reptiles (4/20), the greatest recovery being from young iguanas. Embryonate chicken eggs, white mice, slider turtles, three species of snakes, spectacled caiman, green anoles (an iguanid lizard), leopard frog, and American toad all proved resistant or refractory.

Twelve young iguanas were inoculated with virus by several different routes and held at 23 or $30^{\circ} \mathrm{C}$. Seven animals died during the 15 days of observation, but no pattern of clinical signs was evident. Virus could not be recovered, and histopathological examination was not carried out. When the survivors were sacrificed, virus at low titer was recovered from the spleen of one. In contrast, culture of liver and kidney cells from four of the five survivors gave rise to syncytia within 1-4 weeks. In subsequent work with other vertebrates, culture of tissues from a single Tokay gecko and one of two box turtles revealed iguana virus.

The ultrastructural details of iguana virus were described and profusely illustrated by Zeigel and Clark (1972) (Fig. 4). Capsids of about 115 $\mathrm{nm}$ were found in the nucleus and more specifically in intranuclear inclusions. Capsomere number was estimated to be 162 . Enveloped forms, $225 \pm 75 \mathrm{~nm}$, were found in cytoplasm and in extracellular spaces. A peculiarity of infected-cell cultures was the presence of clusters of 35$\mathrm{nm}$ angular bodies within the nucleus, and in some instances encapsidation of the angular bodies was evident (Fig. 4).

Clark and Karzon (1972), who tested the iguana virus with antisera against one amphibian, one snake, one avian, and seven mammalian herpesviruses, found no neutralizing activity even at dilutions as low as $1: 4$. The iguana virus is therefore considered to be antigenically distinctive, 


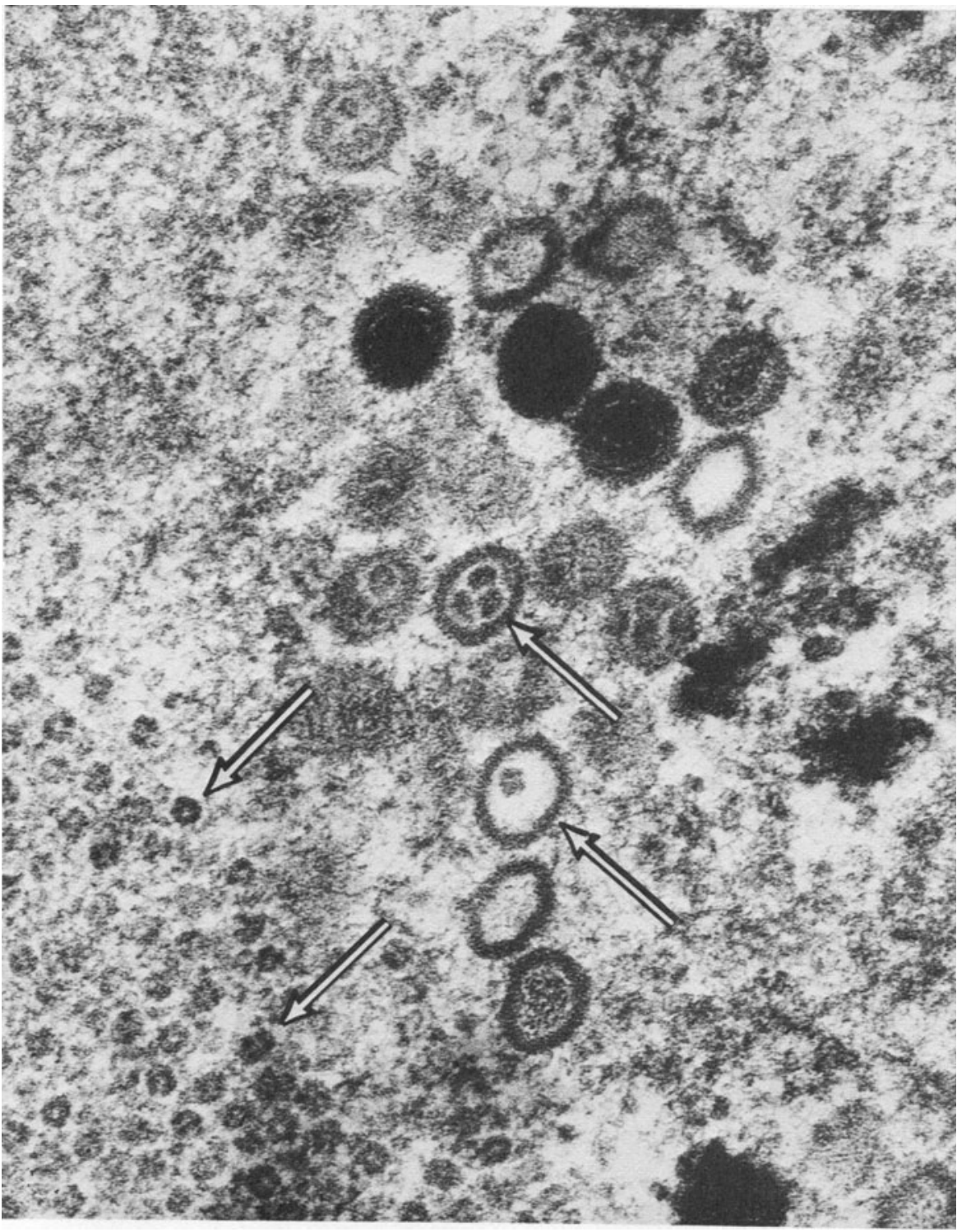

FIGURE 4. Thin section of nucleus of THl cell infected with the iguana herpesvirus. Empty and full capsids are in evidence. Several capsids enclose distinctive 35-nm bodies (center) and lie adjacent to a cluster of similarly shaped bodies (left). $\times 140,000$. From Zeigel and Clark (1972). Reprinted with the permission of the American Society of Microbiology.

but its role in possible disease processes came to light during diagnostic work with animals from another population in California.

Frye et al. (1977) reported on findings in California involving seven iguanas with clinical signs of severe lymphocytosis, anorexia, lethargy, and loss of the normal brilliant green coloration. A single specimen had 
hemorrhaged, and its blood was devoid of thrombocytes. Another had enlarged kidneys. Histologically, all the lizards had severe splenic lymphoid hyperplasia, and most had significant histiocytic lymphoid infiltration of liver, spleen, myocardium, and bone marrow. Although organs were not specified, the authors stated that herpesvirus was found in the cells of two animals and, again without details, stated that host tissue cultures were infected. Morphologically, the virus was said to be similar to that of the Pacific pond turtle.

\section{E. Green Lizard Herpesvirus}

The green lizard (Lacerta viridis) is an Old World terrestrial reptile of the family Lacertidae.

Specimen lizards, some 30-40, were captured in Italy and taken to France, where they were held in a community terrarium with another reptile. Cutaneous plaquelike lesions were found on some of the lizards. Papillomatous in appearance, the 2-25 lesions per animal were 2-20 mm in diameter and usually persisted through hibernation; some, however, were shed at molt. The condition was significantly more common in females $(70 \%)$ than in males, which additionally had only a few lesions. Moreover, the location of lesions differed with sex. Females showed lesions at the base of the tail and trunk, and in males the head and cervical regions were involved. The authors attributed the different locations to results of nuptial activities; biting aggression is directed to the head and neck of competing males, and females are seized by the trunk or base of the tail for copulation (Raynaud and Adrian, 1976). Thus, wounds are inflicted and infection is initiated.

Histologically, the lesions were benign papillomas consisting of hyperkeratinized tissue. Pigment cells occurred at depth, and the epidermis was hypertrophied. In some cells, chromatin had accumulated along the nuclear membrane. Atypical mitoses were not observed; neither was the muscle infiltrated by epidermis, nor were metastases found.

Evidence was found for three different viruses in papillomas from three lizards examined by electron microscopy. A single animal contained what was considered a papovavirus. Two lizards showed two kinds of virions, one considered reovirus and the other conforming to the herpesvirus group; however, neither experimental transmission nor isolation was reported.

\section{F. Elapid Snake Herpesvirus}

The banded krait (Bungarus fasciatus), Indian cobra (Naja naja), and Siamese cobra (Naja naja kaouthia) are poisonous terrestrial snakes of the family Elapidae and collectively are native to eastern Asia and India. 
The snakes are widely exported to zoological gardens for display and to herpetaria and research laboratories. Herpesvirus has been found in the venom or venom glands of all three species, but no biological isolations have been made. Considering the relatedness of the three snakes and their geographic origin, it is conservatively prudent to discuss the associated herpesvirus as a single entity. Isolation and serological identification will provide definitive answers.

Herpesvirus of elapid snakes came to light with the work of Padgett and Levine (1966), who used reconstituted lyophilized crude venoms from the Indian cobra and banded krait in attempting to determine structural details of Rauscher leukemia virus. Their results showed herpesviruslike details previously unknown for, and inconsistent with, the Rauscher agent. Monroe et al. (1968) saw reason to question the findings and carried out a direct investigation of the two venoms themselves. Electron microscopy of thin sections and of negatively stained preparations showed that the venoms contained herpesvirus particles and considerable cellular debris. Clearly, the herpesvirus was a contaminant of the venoms and not structurally altered Rauscher virus.

Monroe et al. (1968) found both enveloped and nonenveloped particles and aggregates of virions numbering up to a hundred. Capsid size was $100-125 \mathrm{~nm}$. Hollow capsomeres were visualized; they had lengths

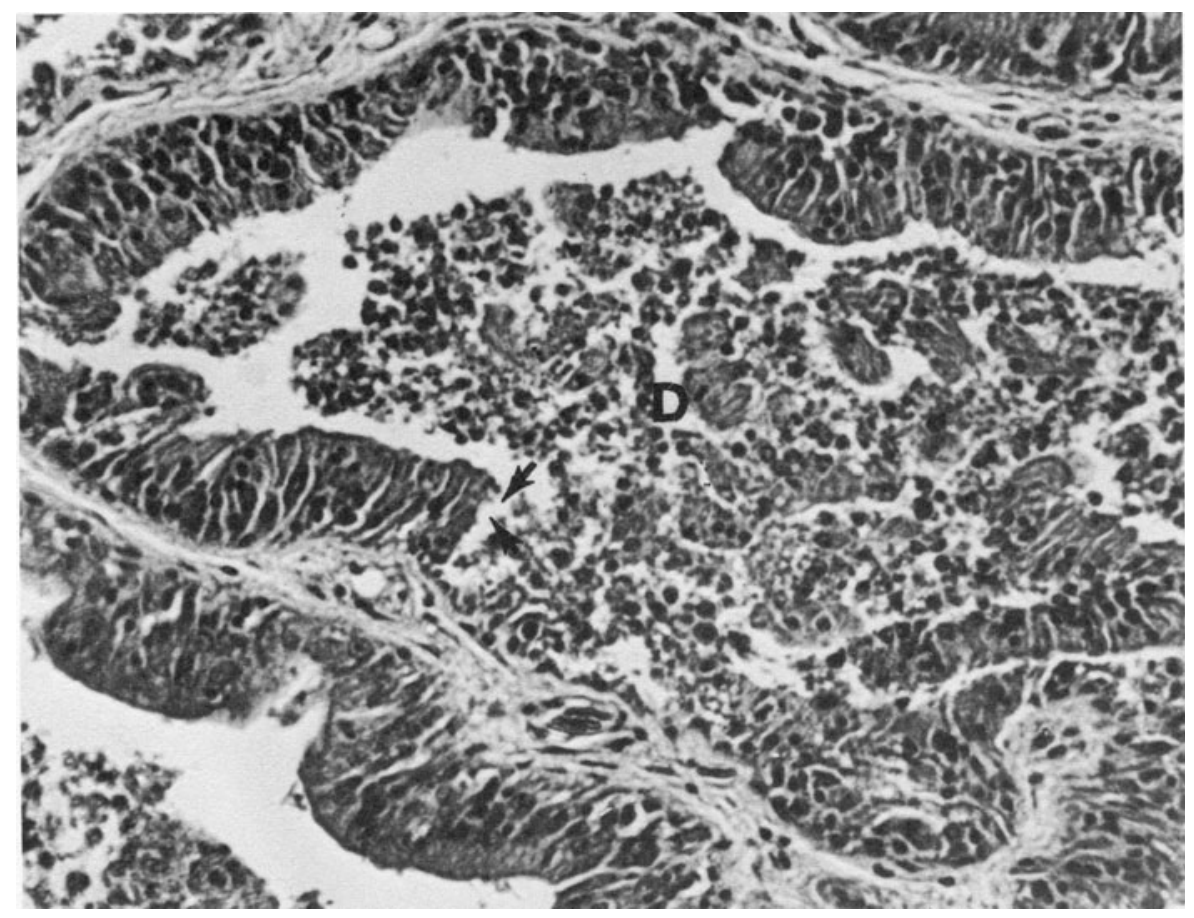

FIGURE 5. Section of Siamese cobra kidney showing patches of necrotic tubular epithelium and debris (D) in the lumen. Hematoxylin-eosin. $\times 125$. From Simpson et al. (1979). Reprinted with the permission of the American Veterinary Medical Association. 


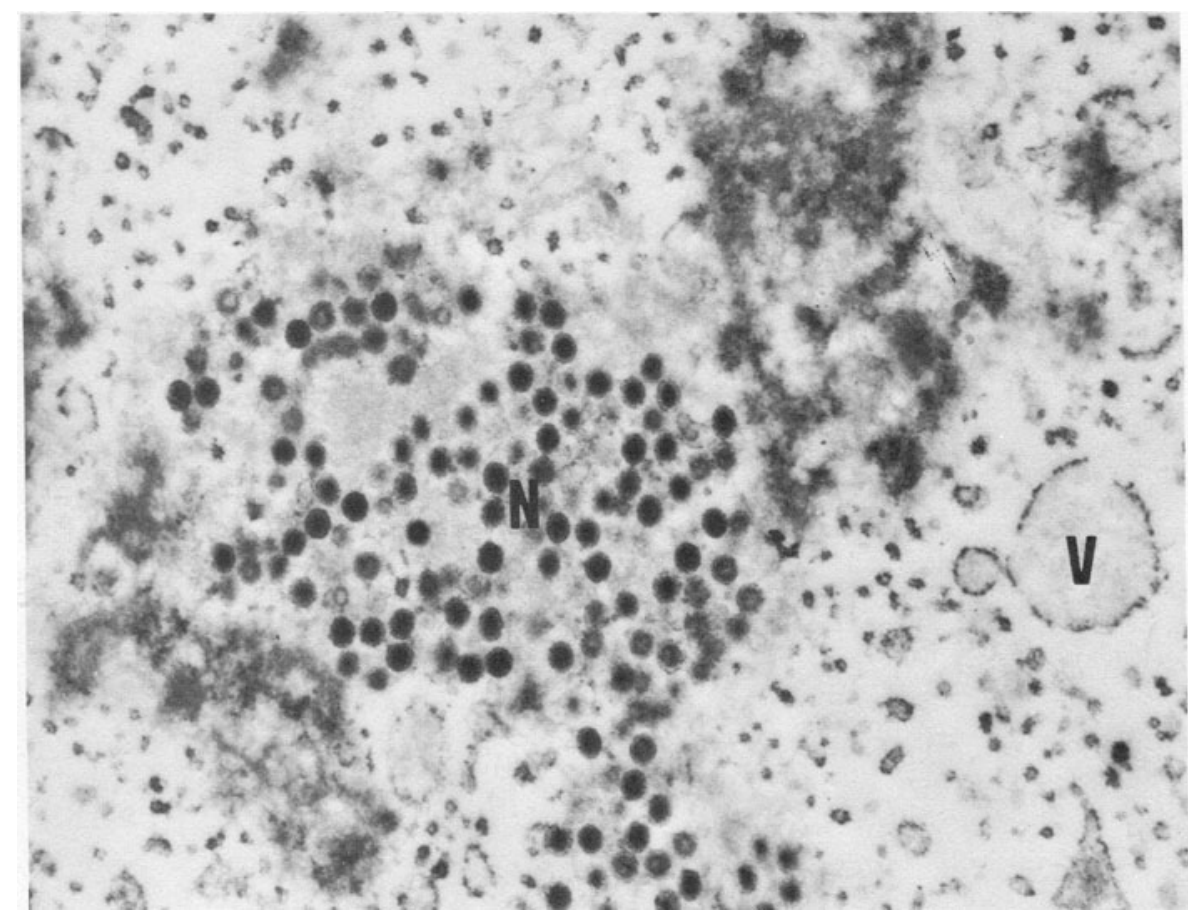

FIGURE 6. Thin section of Siamese cobra venom gland. Nucleocapsids (N) have been released from a cell nucleus into the lumen of a gland. Venom (V) occurs in coated vesicles. $\times 25,000$. From Simpson et al. (1979). Reprinted with the permission of the American Veterinary Medical Association.

of $12 \mathrm{~nm}$ and diameters of about $8 \mathrm{~nm}$. Capsomere number, however, could not be determined.

Thus far, there was no indication of effects that the virus had on the host snakes.

Simpson et al. (1979) added to the list of snakes with herpesvirus and in a sense provided the first clue to effects on the host. The Siamese cobra was the newly recognized source animal, and the reason for the discovery was that $20 \%$ of a shipment of 400 snakes from Thailand produced lowgrade venoms that were abnormally thick. The condition was due to cellular contamination.

Simpson's group excised the venom glands of two specimens and prepared them for light and electron microscopy. The glands were enlarged, and lumens of some tubules contained appreciable cell debris. In limited areas, squamous epithelium was necrotic (Fig. 5). Microvilli were absent from surfaces of degenerated cells, and mononuclear infiltration was present in subepithelium of affected glands.

Electron microscopy of attached epithelial cells showed margination of nuclear chromatin and naked intranuclear capsids of $95-115 \mathrm{~nm}$. Capsids were also found in necrotic cells (Fig. 6), and cell-free enveloped particles, 190-210 nm, were present in lumens of some venom glands. 
Virus isolation attempted on viper heart cell cultures was not successful. The failure was attributed to cellulytic enzymes present in venom gland homogenate; inoculated cell sheets sloughed within $12 \mathrm{hr}$.

It is tantalizing to consider experimental transmission to young elapids, possible systemic infection, and possible isolation from internalorgan homogenates that would not be toxic to cell cultures.

\section{TELEOST FISH HERPESVIRUSES}

\section{A. Oncorhynchus masou Virus}

Members of the genus Oncorhynchus are Pacific salmon native to the higher latitudes of the northern hemisphere. They are mainly anadromous, but some small populations have become isolated and landlocked. An agent Oncorhynchus masou virus (OMV) was isolated from a landlocked population of Oncorhynchus masou, or masu salmon, a species native to Japan.

Initially during 1978, but again in the following year, Kimura et al. (1981a-c) isolated OMV during the course of a virological survey of propagated salmonids on Hokkaido. The source material was ovarian fluid from landlocked masu salmon that were of normal appearance but the population history of which showed a pattern of low survival among the progeny fry.

OMV has been sufficiently characterized to be firmly placed in the herpesvirus group (Kimura et al., 1981a). Cultures of RTG-2, CHSE-214, KO-6, and other salmonid cell lines are susceptible; they show an initial rounding that is followed by syncytium formation and a terminal lysis. Small eosinophilic inclusions are present in the cytoplasm of infected cells. Commonly used nonsalmonid fish cell lines are refractory to OMV. The agent is both ether- and acid-labile $(\mathrm{pH} 3.0)$ and does not hemagglutinate human $\mathrm{O}+$ cells. Replication is inhibited by levels of $50 \mu \mathrm{g} / \mathrm{ml} \mathrm{5-}$ iodo-2-deoxyuridine (IUdR), by phosphonacetate, and by acycloguanosine. Growth range is from 5 to $18^{\circ} \mathrm{C}, 15^{\circ} \mathrm{C}$ being optimal, and $25^{\circ} \mathrm{C}$ being nonpermissive. A one-step growth curve requires about 9 days, and maximal titer is about $10^{6}$ median tissue-culture infectious doses $\left(\mathrm{TCID}_{50}\right) /$ $\mathrm{ml}$. The agent's infectivity holds for at least 6 months at $-80^{\circ} \mathrm{C}$, but at $-2^{\circ} \mathrm{C}, 99.9 \%$ of the infectivity is lost in 17 days. At temperatures of $15^{\circ} \mathrm{C}$ or higher, loss of infectivity is complete in 17 days.

Serologically, OMV is distinctive; it is neutralized by homologous antiserum but not by antiserum against any of the other salmonid viruses; infectious pancreatic necrosis, infectious hematopoietic necrosis, Egtved virus (viral hemorrhagic septicemia), or Herpesvirus salmonis.

Electron microscopy of infected cells shows hexagonal intranuclear capsids with a diameter of $115 \mathrm{~nm}$. Particles in the process of budding 
are also found, and completely enveloped virions measure $200 \times 240 \mathrm{~nm}$. The calculated number of capsomeres is 162 .

Successful experimental infection of young salmonids is readily accomplished by simple immersion in a suspension of OMV. There is evidence, however, that, as in the channel catfish herpesvirus, nonspecific resistance develops with age. Kimura et al. (1981a,c) exposed 1003 month-old and 50 5-month-old chum salmon (O. keta) to $100 \mathrm{TCID}_{50} /$ $\mathrm{ml} \mathrm{OMV}$ for $1 \mathrm{hr}$ at $10^{\circ} \mathrm{C}$ and held the fish for observation at $10-15^{\circ} \mathrm{C}$. Mortality began among the younger fry at 11-12 days and among the older fry at about 20 days. During the next 50 days, $60 \%$ of the younger fry and $35 \%$ of the older fry died. Less than $5 \%$ of each control group died during the same period. Similar infection by immersion, followed by intraperitoneal injection of 200 TCID $_{50}$ virus, was tried with 8-monthold fish, but there was no evidence of susceptibility. Fish-to-fish transmission was effected by holding 5-month-old fry with fry that had been infected by immersion; the resulting mortality resembled that described for the original infection by immersion.

Coho salmon (O. kisutch), kokanee (O. nerka), and rainbow trout (Salmo gairdneri) proved to be susceptible to experimental inoculation with OMV.

Clinically, fry infected with OMV were inappetent and exophthalmic; they had petechiae on body surfaces and especially beneath the lower jaw. Internally, livers were mottled with white, and in advanced cases the whole liver was pearly white. The digestive tract was devoid of food, and in some fish, the spleen was swollen. The kidneys, prime targets for bacterial and viral pathogens of fish, appeared to be normal.

Histopathological examination revealed numerous foci of severe hepatocyte necrosis and syncytium formation in the liver (Kimura et al., 1981a). Cardiac muscle was edematous, and partial necrosis was evident in some spleen sections. Pancreatic and renal tissues were essentially normal. Although specifics were not given, Kimura et al. (1981a) stated that necrosis was evident in all vital organs of month-old fish.

Electron microscopy of liver from infected fish showed intranuclear virus particles, some empty and some with nucleoids. Enveloped particles were found, but only infrequently.

The most interesting feature of OMV was the development of neoplasms among survivors of experimental infection (Kimura et al., $1981 \mathrm{~b}, \mathrm{c})$. Beginning at about 4 months and persisting at least 8 months postinfection, $60 \%$ of the 5 -month-old chum salmon survivors developed tumors of differentiated epithelium. The growths occurred mostly about the head, on the mouth, under the gill covers, on the eyes, and sometimes on the caudal fin. One of the 52 survivors had a tumor in the kidney. Control fish held under the same conditions showed no tumors; accordingly, OMV is presumed to play a role in neoplasm induction.

Structurally, the neoplasms were papillomas of abnormally proliferating squamous epithelium, supported by a stroma of fine connective 
tissue (Kimura et al., 1981b). Mitoses were abundant, but necrosis was absent in all but the single renal tumor; that growth displaced normal kidney tissues. Electron microscopy showed variability in nuclear size, but viral particles were not evident.

When virological examination was carried out on the neoplasms (liver, kidneys, heart, and spleen) of 11 tumor-bearing fish, serologically identified OMV was isolated from one of the tumors. Another tumor that was cultured showed cell outgrowth during the first 4 days; cytopathic effect (CPE) then appeared, and virus was recovered.

Kimura et al. (1981b) made a point of noting that tumor induction among chum salmon surviving experimental OMV infection was confirmed in additional work carried out during the year following their original observation. Time for tumor induction again was about 4 months. Moreover, coho salmon that survived experimental infection also developed tumors.

Virus-neutralizing activity against OMV was found in the serum from some of the normal and tumor-bearing survivors. Titers against 100 TCID $_{50}$ virus were $1: 160$ from those with neoplasms and 1:320 from those without tumors. Sera from uninoculated controls had titers of less than $1: 20$.

Many intriguing questions present themselves. First and foremost, are epithelial neoplasms evident on any of the spawning adult population? Second, is poor survival of progeny fry attributable to OMV? Do adults possess serum neutralizing activity against $O M V$, and if so, is there a correlation with presence or absence of the virus? One wonders too whether this particular herpesvirus is incorporated in the genome of the neoplastic cells. The existence of OMV in Japan and the single instance of $H$. salmonis in America lead to the question of whether they are one and the same agent. Kimura et al. (1981a) found that OMV antiserum did not neutralize $H$. salmonis. Early results of work with the two agents at the National Fish Health Research Laboratory have shown that the CPE of the two is distinctly different.

\section{B. Herpesvirus salmonis (Salmonid Herpesvirus Disease)}

Kokanee, also known in Japan as himemasu, are landlocked forms of Oncorhynchus nerka, a Pacific salmon. The rainbow trout is native to North America but widely introduced elsewhere in both hemispheres. The rainbow trout and kokanee are members of the family Salmonidae, and both fishes are highly regarded for sport and food. In North America, the annual production of rainbow trout exceeds 22 million $\mathrm{kg}$, most of which is marketed as a fresh or frozen or otherwise processed product. In the United States, an agent subsequently named Herpesvirus salmonis (on deposit with the American Type Culture Collection) has been isolated from rainbow trout and a similar virus from O. nerka in Japan. 
Investigations of excessive postspawning mortality among fish in a hatchery population of rainbow trout in the Pacific Northwest of the United States led to isolation of a virus in 1971. Identification was sought, but the agent was lost before a determination could be made. Additional isolations were made over the next several years, but it was not until 1975 that confirmation of the viral nature of the agent was obtained, the reason being that for reliable replication, incubation had to be at $10^{\circ} \mathrm{C}$ or less-lower than temperatures normally used for replicating viruses of coldwater fishes (Wolf et al., 1978). In the meantime, Sano (1976) investigated annual epizootics among landlocked O. nerk $a$ fry that resulted in $80 \%$ mortality and had a history of occurrence since 1970 . Sano also incubated cultures at $10^{\circ} \mathrm{C}$, and concluded that the Nerka virus in Towanda Lake, Akita and Aomori Prefectures (NeVTA), was herpeslike, but that it differed from $H$. salmonis. Discussions by the American and Japanese investigators and comparisons of cell-culture results and histopathological changes led to the conclusion that $H$. salmonis and NeVTA were closely related and possibly identical (Wolf et al., 1975). Serum neutralization tests have not been carried out; $H$. salmonis is poorly antigenic. Accordingly, and in view of the report by Kimura et al. (1981a), the possibility must be considered that NeVTA virus is the same as OMV and not $H$. salmonis.

Experimental inoculation of fry or small fingerling rainbow trout with $H$. salmonis and subsequent maintenance of the fish at $6-9^{\circ} \mathrm{C}$ resulted in a subacute to chronic viscerotropic disease with marked edema and necrosis and a heretofore unknown induction of syncytia in fish pancreatic acinar tissue (Wolf and Smith, 1981).

Behavior of young rainbow trout is characterized by anorexia and lethargy, with some victims showing loss of motor stability but maintaining a capability of brief bursts of erratic swimming when alarmed.

The first observable external sign is the presence of thick whitish mucoid casts trailing from the vent. Later, many of the fish have a distended abdomen and darken appreciably (Fig. 7). Marked exophthalmia is common, and hemorrhages may occur in the orbits and at the base of fins. The gills are pale.

Gross internal findings show overall pallor of the visceral mass. The body cavity contains slight to abundant amounts of ascitic fluid that may or may not be gelatinous. The anterior digestive tract is empty, but if any food is present, it is in the hind gut or rectal area. Viscera are flaccid; the liver may be mottled or hemorrhagic. Kidneys are pale but not obviously swollen. Limited hematological examination showed that peripheral blood contains blast cells and many immature red blood cells, but no cellular debris.

Major histopathological changes occur throughout the viscera, notably in the kidneys, respiratory organs, heart, digestive tract, and liver. Syncytia are produced in pancreatic acinar tissue (Fig. 8) and are considered pathognomonic for H. salmonis infection (Wolf and Smith, 1981). 


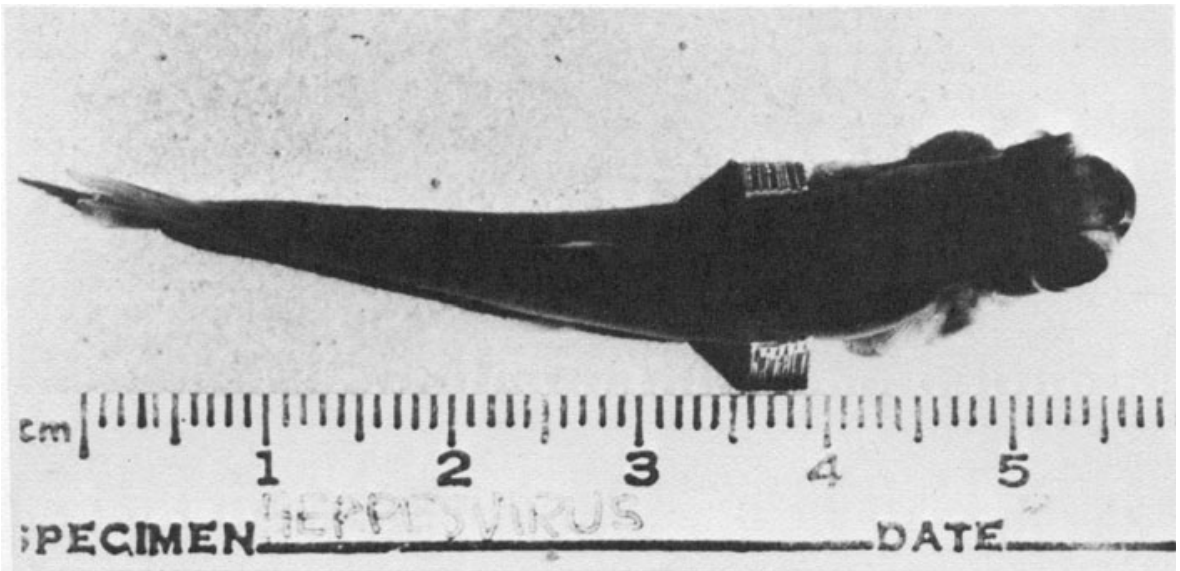

FIGURE 7. Rainbow trout fry that died as a result of experimental infection with $\mathrm{H}$. salmonis. Notable features are marked melanism, distended abdomen, and severe exophthalmia. Courtesy of H. M. Stuckey.

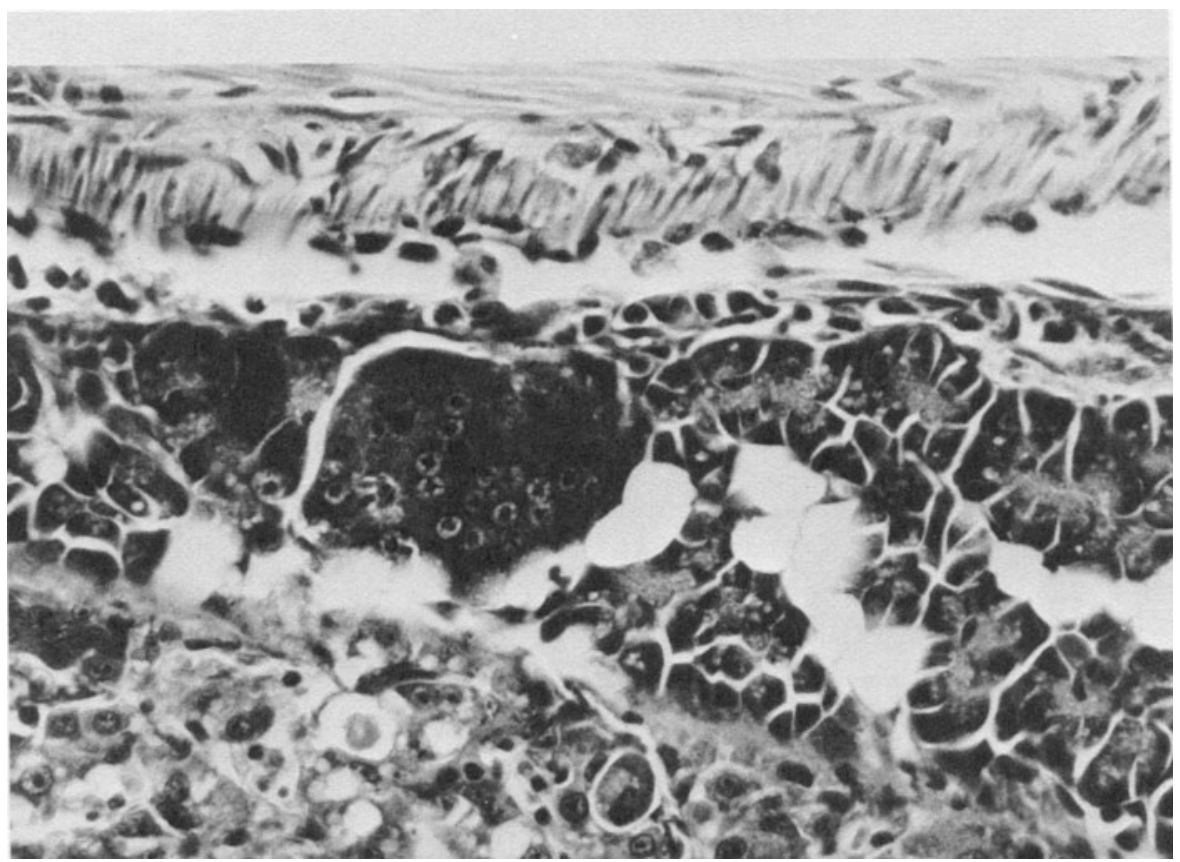

FIGURE 8. Syncytia in pancreatic acinar cells (left center) of rainbow trout fry parenterally infected with $H$. salmonis. Normal pancreatic tissue is at right center. Liver tissue at lower left is necrotic. Hematoxyin-eosin. $\times 200$. From Wolf and Smith (1981). Reprinted with the permission of Blackwell Scientific Publications Ltd. 
Kidneys show some hyperplasia of hematopoietic tissue, and generalized edema. Slight to moderate necrosis is evident in renal tubules, and some have serous material in the lumen. Glomeruli in general appear normal. Viral infectivity is highest in kidney tissues. Edema is widespread in the liver, and some specimens have areas of necrosis and hemorrhage or congestion (Fig. 8). Focal vacuolation is found in some livers. Cardiac tissue is grossly edematous and necrotic, and there is marked leukocytic infiltration involving both lymphocytes and polymorphonuclear cells. Gill epithelium shows edema and hypertrophy. Some lamellar epithelium separates from underlying connective tissue (Fig. 9), and a few specimens have gill hemorrhages. Pseudobranchs are typically edematous, and cell nuclei are hypertrophied and some have margination of chromatin (Fig. 10). Localized necrosis of pseudobranchs is slight to moderate. Edema of stomach tissue occurs in about half the specimens. The anterior intestine is mostly normal, but the hind gut or rectum has areas of marked necrosis, foci of infiltrating leukocytes in the submucosa, and frank sloughing of the mucosa into the lumen (Fig. 11). Sloughed mucosa undoubtedly constitutes the bulk of the fecal pseudocasts seen externally. Lesser changes are found in the eyes, spleen, brain, and ovaries of some specimens.

Herpesvirus salmonis in infected-cell cultures has a capsid size of 90-95 nm (Fig. 12), and enveloped forms are about $150 \mathrm{~nm}$ in diameter (Fig. 13). Nuclear replication and envelopment in the cytoplasm are typ-

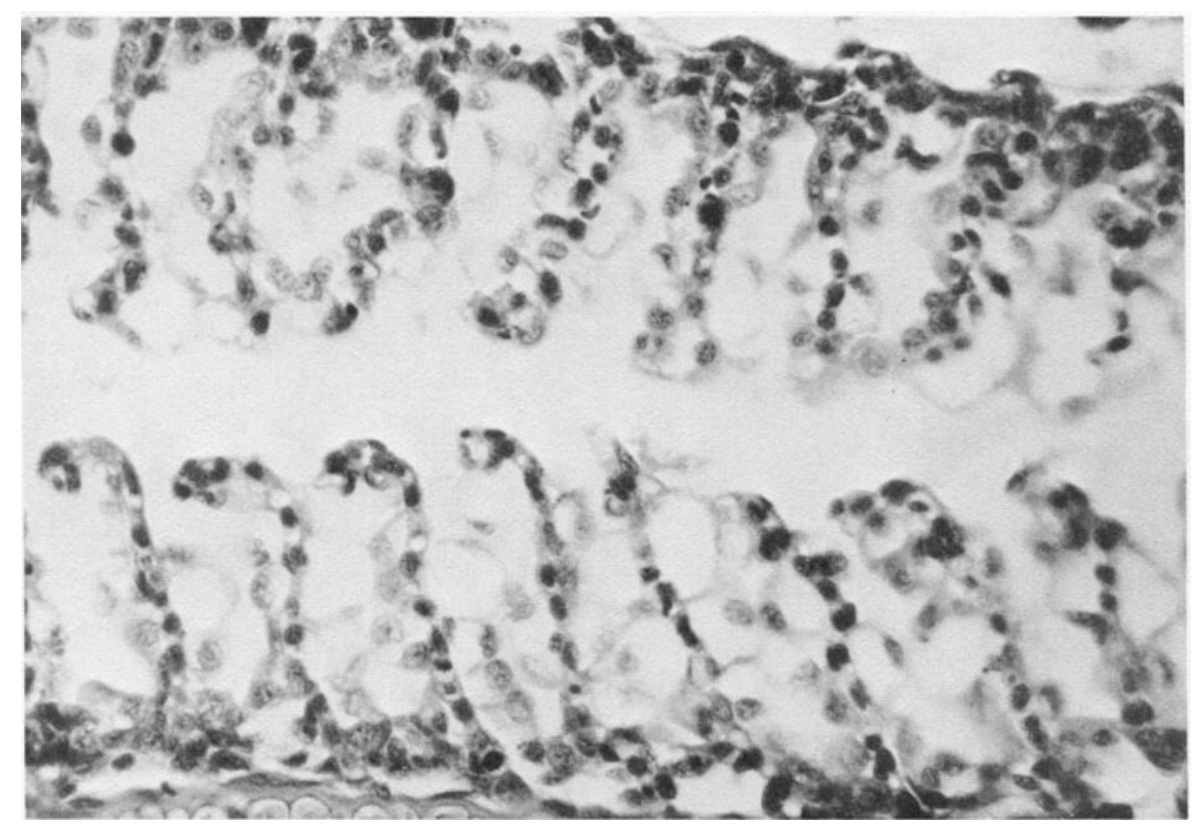

FIGURE 9. Edema and hypertrophy of gill lamellar epithelium in rainbow trout fry parenterally infected with $H$. salmonis. Hematoxylin-eosin. $\times 200$. From Wolf and Smith (1981). Reprinted with the permission of Blackwell Scientific Publications Ltd. 


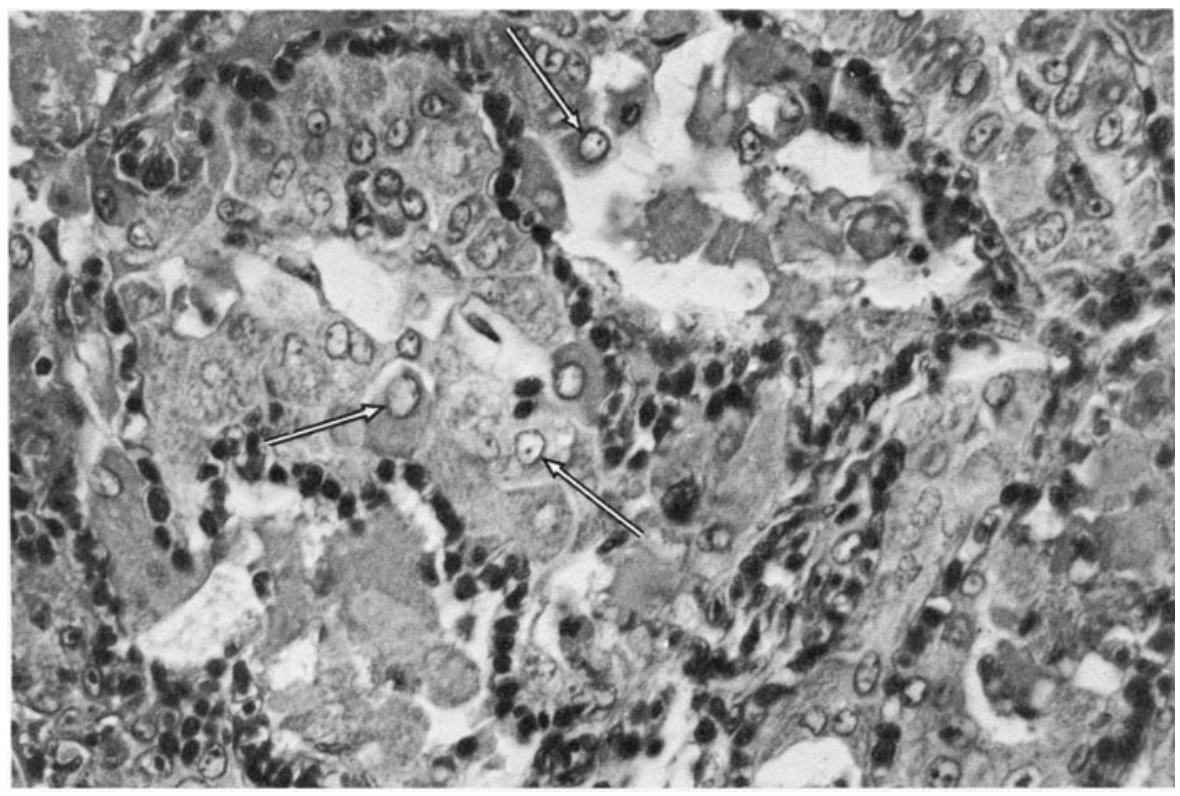

FIGURE 10. Edema, necrosis, and cellular hypertrophy in pseudobranch of rainbow trout fry parenterally infected with $H$. salmonis. Margination of chromatin (arrows) is common in hypertrophied cell nuclei. Hematoxylin-eosin. $\times 200$. From Wolf and Smith (1981). Reprinted with permission of Blackwell Scientific Publications Ltd.

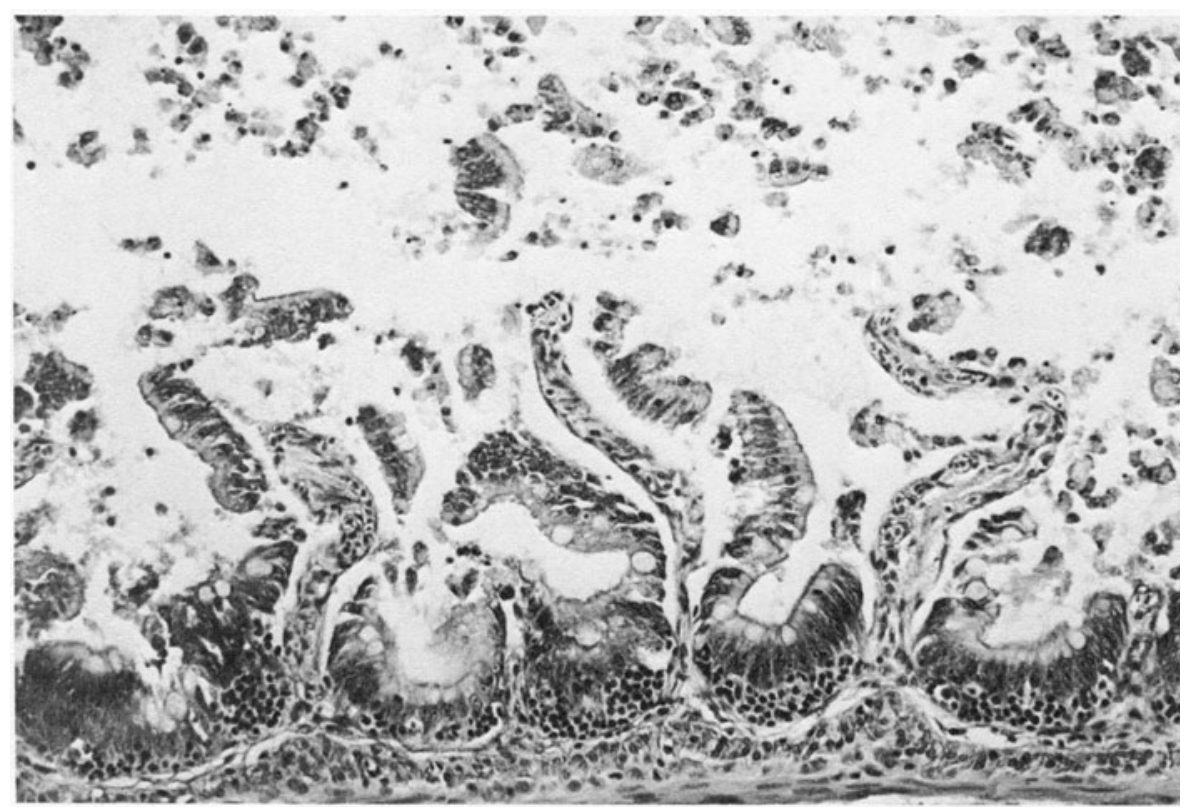

FIGURE 11. Advanced necrosis, mucosal sloughing, and leukocytic infiltration of the submucosa of rainbow trout fry parenterally infected with $H$. salmonis. Hematoxylin-eosin. $\times 80$. From Wolf and Smith (1981). Reprinted with the permission of Blackwell Scientific Publications Ltd. 


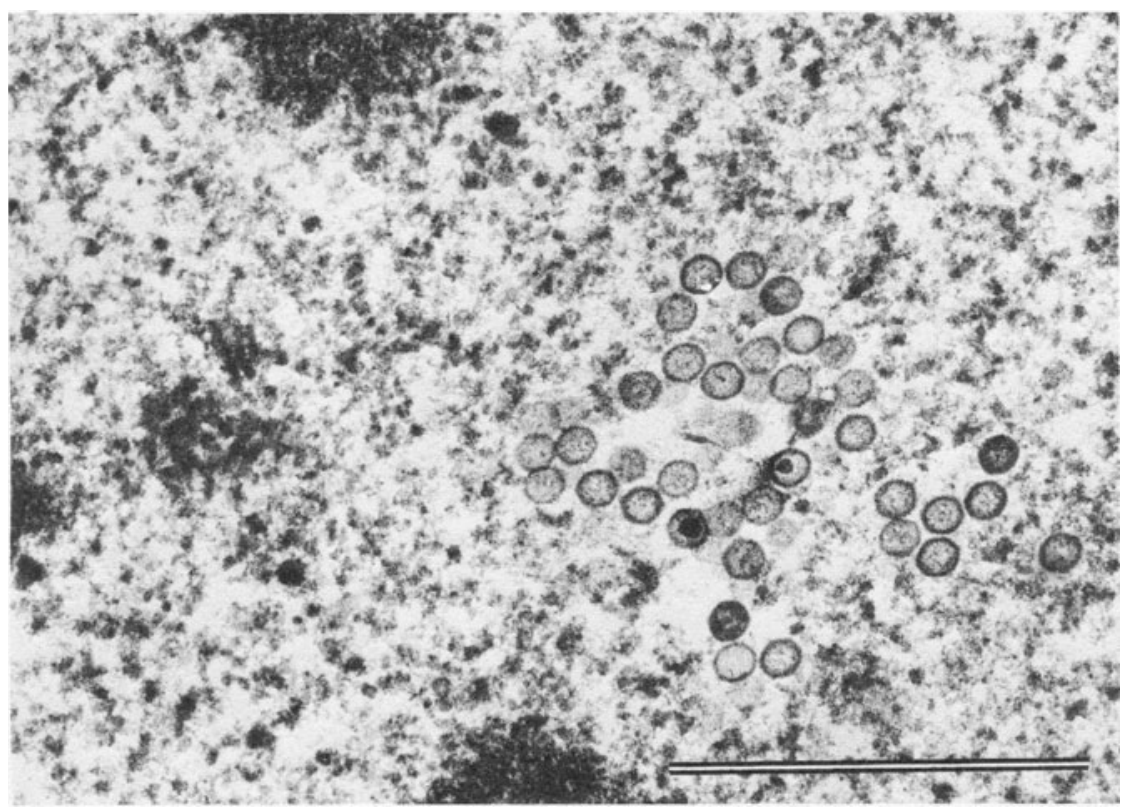

FIGURE 12. Portion of nucleus of RTG-2 cell infected with $H$. salmonis. Empty and full capsids in various stages of maturation. Scale bar: $1000 \mathrm{~nm}$. From Wolf et al. (1978). Reprinted with the permission of the American Society of Microbiology.

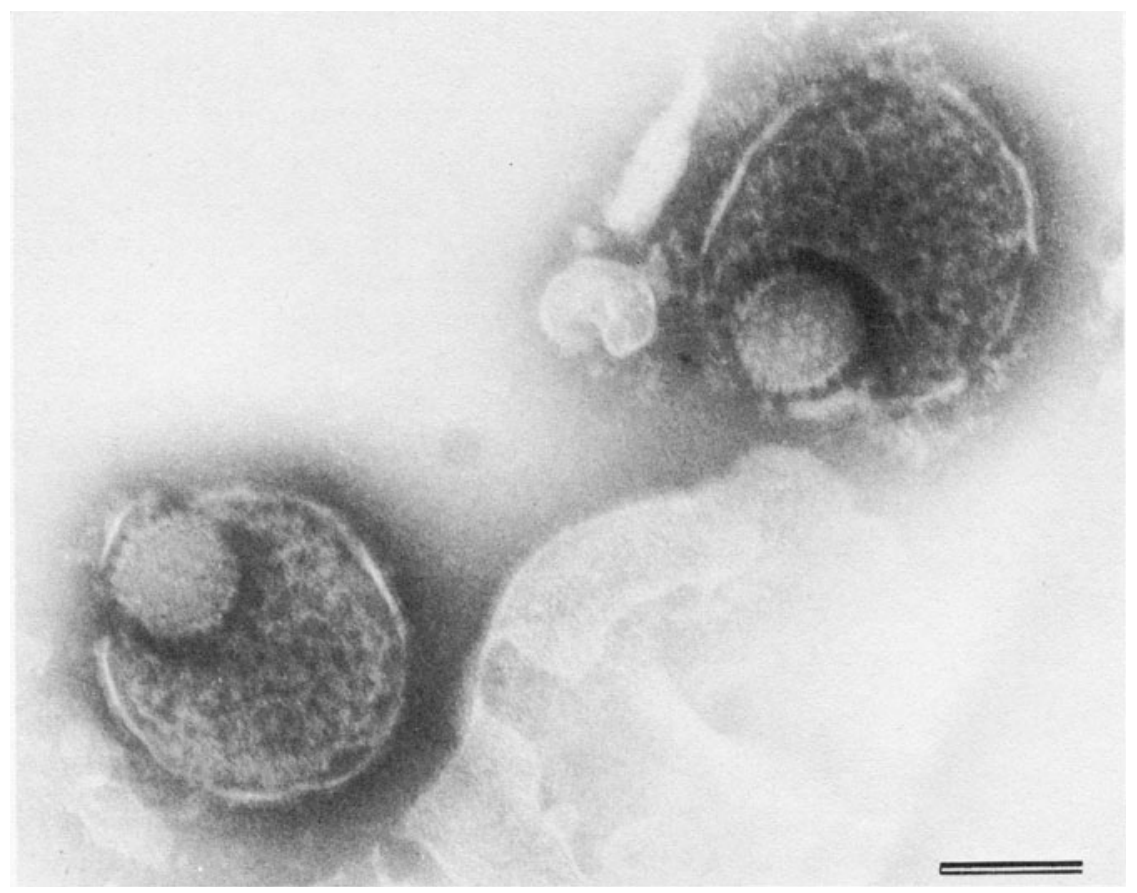

FIGURE 13. Negatively stained enveloped particles of $H$. salmonis Scale bar: $100 \mathrm{~nm}$. From Wolf $e$ t al. (1978). Reprinted with the permission of the American Society of Microbiology. 
ical of the group. Electron-dense lamellar or fibrillar material occurs in the nucleus and, though less abundant, resembles that seen in channel catfish virus infections (Fig. 14). Viral DNA has a buoyant density of 1.709 and a guanosine plus cytosine $(\mathrm{G}+\mathrm{C})$ value of $50 \%$. As expected, the agent is ether- and acid-labile and without hemagglutinating capacity for human $\mathrm{O}+$, rabbit, or rainbow trout erythrocytes. Replication occurs at $5-10^{\circ} \mathrm{C}$, but is erratic at $15^{\circ} \mathrm{C}$ and does not occur at higher temperatures. The virus induces fusion of trout cells incubated at $0^{\circ} \mathrm{C}$, but no replication occurs. The cryophilic nature of $H$. salmonis is also evident in its adsorption; other trout and salmon viruses are usually adsorbed for 30-60 min at $15^{\circ} \mathrm{C}$, but $H$. salmonis must be adsorbed for at least $120 \mathrm{~min}$ at $10^{\circ} \mathrm{C}$ to achieve the full complement of plaques (Fig. 15).

The agent is replicated by the salmonid cells RTG-2, RTF-1, KF-1, and CHSE-214, but not by cell lines from nonsalmonid fish species. A one-step growth curve in RTG-2 cells at $10^{\circ} \mathrm{C}$ requires more than 4 days for completion (Fig. 16). At $24 \mathrm{hr}$, new virus appears in concert with formation of the earliest syncytia. Exponential growth takes place from 24 to $60 \mathrm{hr}$, and cell-associated virus exceeds released virus by a factor of about 10. Peak titers are achieved at $4-5$ days, released virus attaining

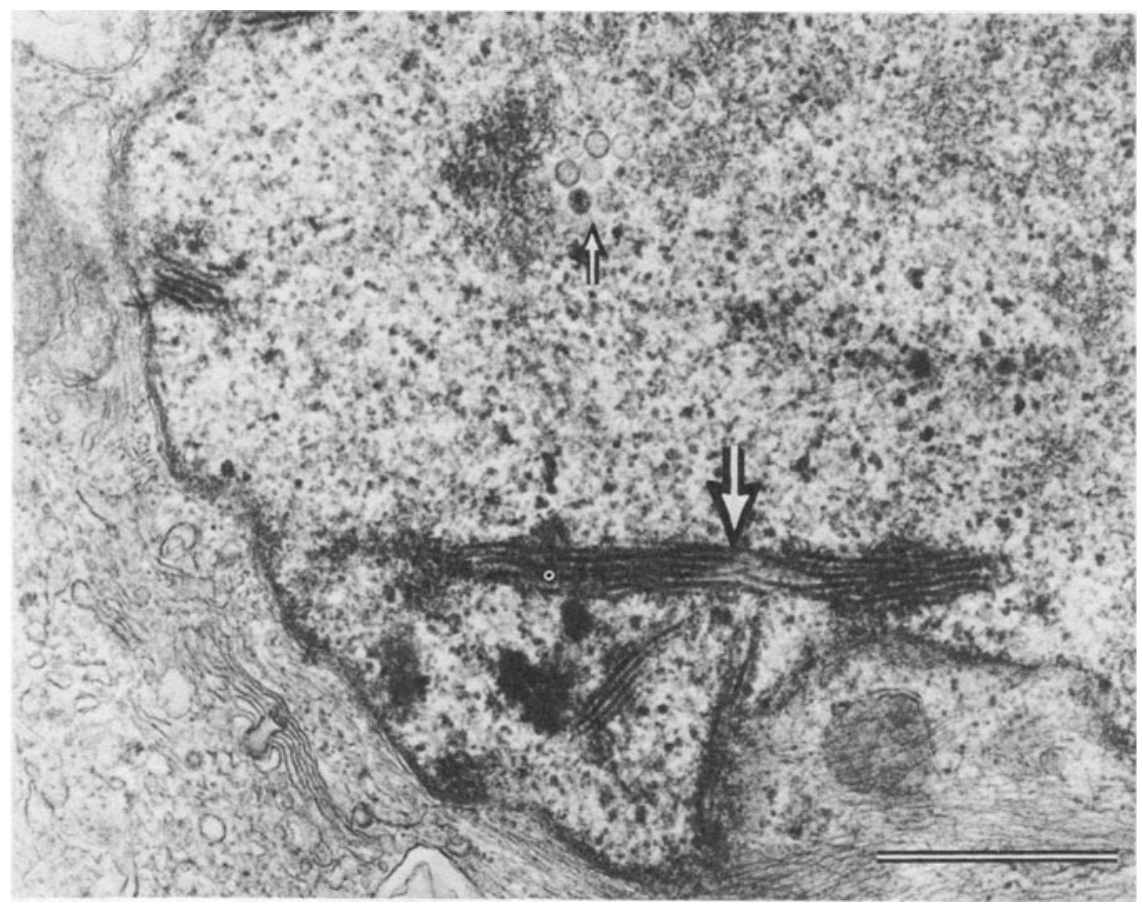

FIGURE 14. Portion of nucleus of RTG-2 cell infected with $H$. salmonis. Developing particles are indicated by small arrow and electron-dense fibrillar or lamellar material by large arrow. Scale bar: $1000 \mathrm{~nm}$. From Wolf et al. (1978). Reprinted with the permission of the American Society of Microbiology. 


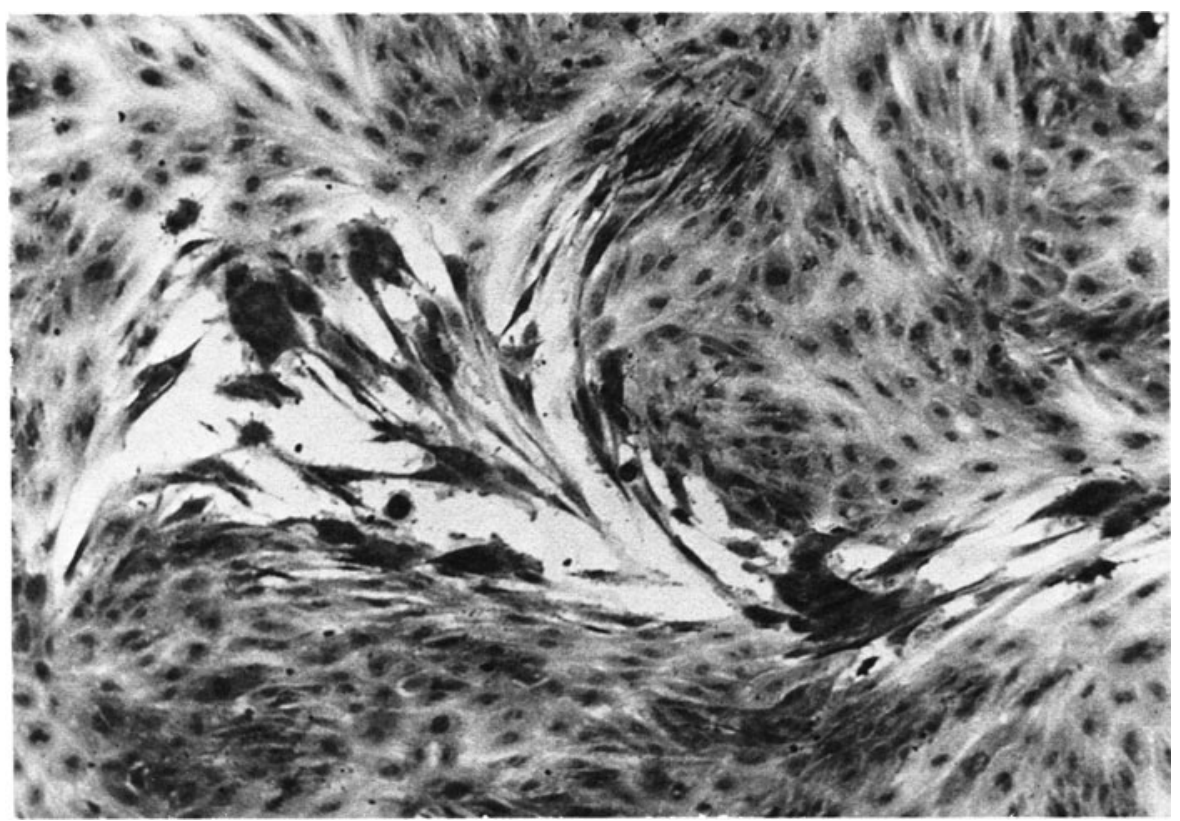

FIGURE 15. Plaque of $H$. salmonis in RTG-2 cells. Note that viral effects preferentially follow linear patterns within cell sheet. Crystal violet stain. From Wolf et al. (1978). Reprinted with the permission of the American Society of Microbiology.

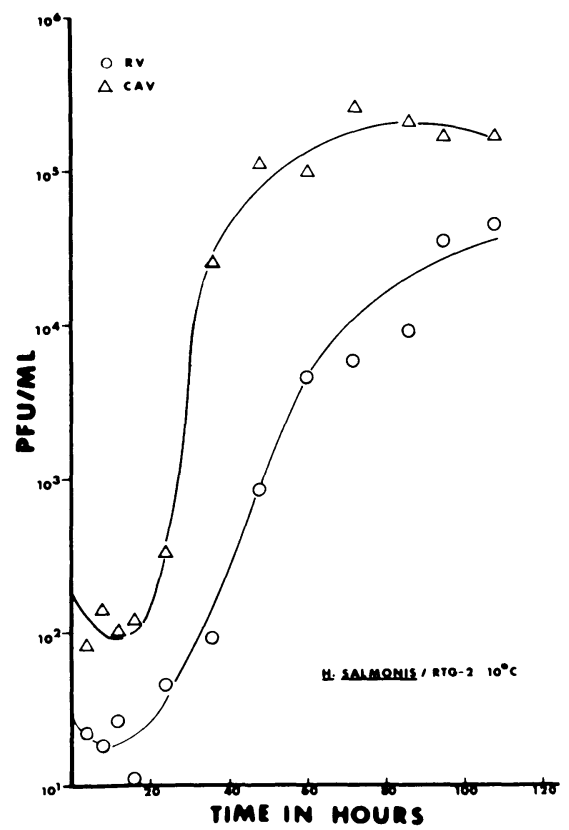

FIGURE 16. One-step growth curve of $H$. salmonis in RTG-2 cells at $10^{\circ} \mathrm{C}$. (RV) Released virus; (CAV) cell-associated virus. From Wolf et al. (1978). Reprinted with the permission of the American Society of Microbiology. 
about $5 \times 10^{4}$ plaque-forming units $(\mathrm{PFU}) / \mathrm{ml}$ and cell-associated virus about $3 \times 10^{5} \mathrm{PFU} / \mathrm{ml}$.

Morphological changes in infected-cell cultures begin with some rounding and increase in refractility (Fig. 17). Syncytium formation follows and lysis ensues. However, the lytic phase is not complete, and intact cell aggregates persist for days or even weeks. Stained cell sheets show basophilia, margination of nuclear chromatin, and Cowdry Type A intranuclear inclusions (Fig. 18).

Three cycles of freezing and thawing do not degrade infectivity of $H$. salmonis, but if the $\mathrm{pH}$ is 7.6 or greater, the agent is somewhat labile at -20 or even $-80^{\circ} \mathrm{C}$. Virus held at $4^{\circ} \mathrm{C}$ in culture medium without serum loses more than $99 \%$ of its infectivity within 3 weeks. Preferred storage is in infected-cell cultures in medium containing at least $10 \%$ serum, and at $-80^{\circ} \mathrm{C}$. Under these conditions, only $10 \%$ infectivity was lost in 18 months. Effects of lyophilization are not known.

Rainbow trout less than 6 months old and kept at $6-9^{\circ} \mathrm{C}$ are vulnerable to $H$. salmonis administered by injection, and among several trials the cumulative mortality ranged from 50 to $100 \%$. Yearling rainbow trout are wholly resistant to $H$. salmonis. Under similar conditions, young

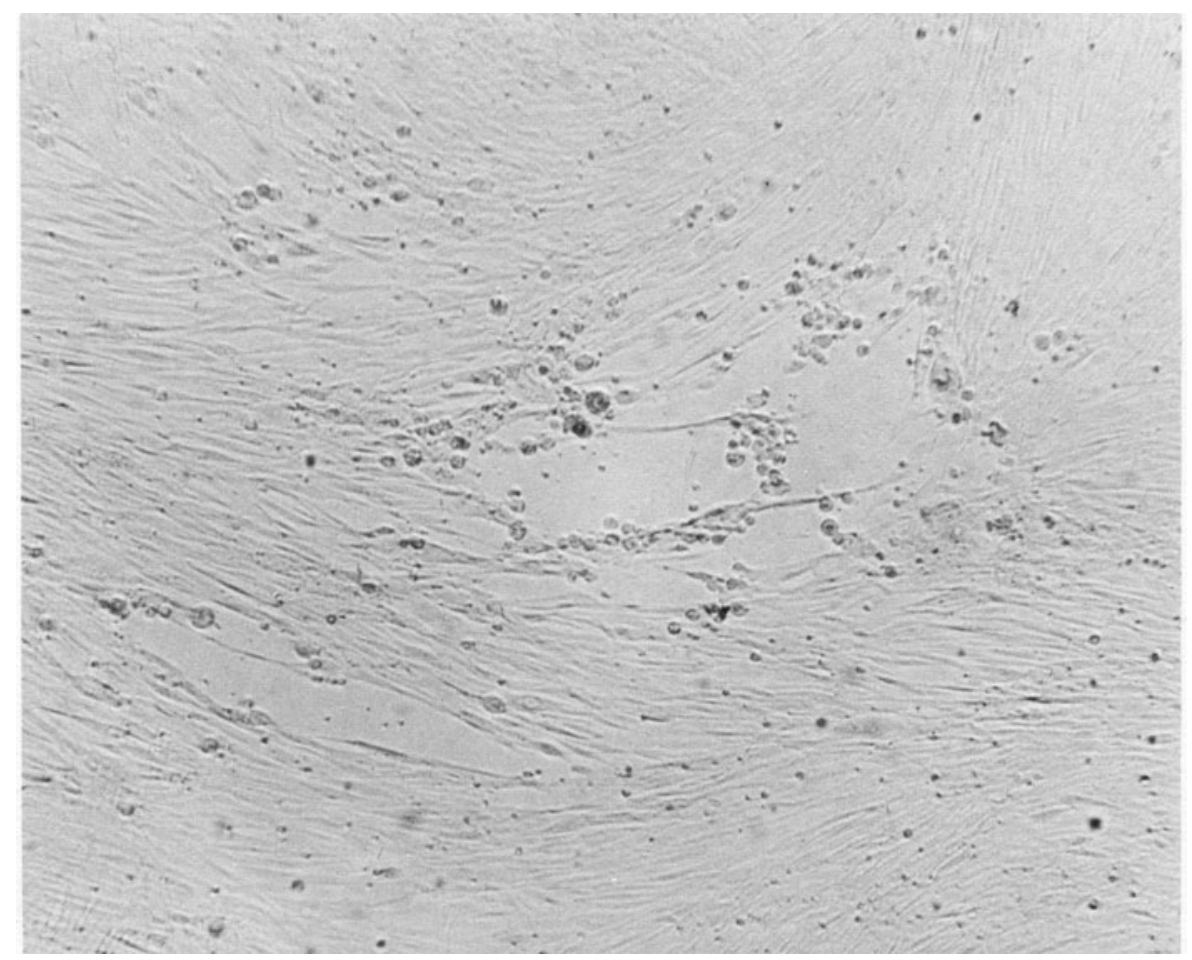

FIGURE 17. Living sheet of RTG-2 cells infected with $H$. salmonis showing characteristic foci of rounded cells and early evidence of fusion. 

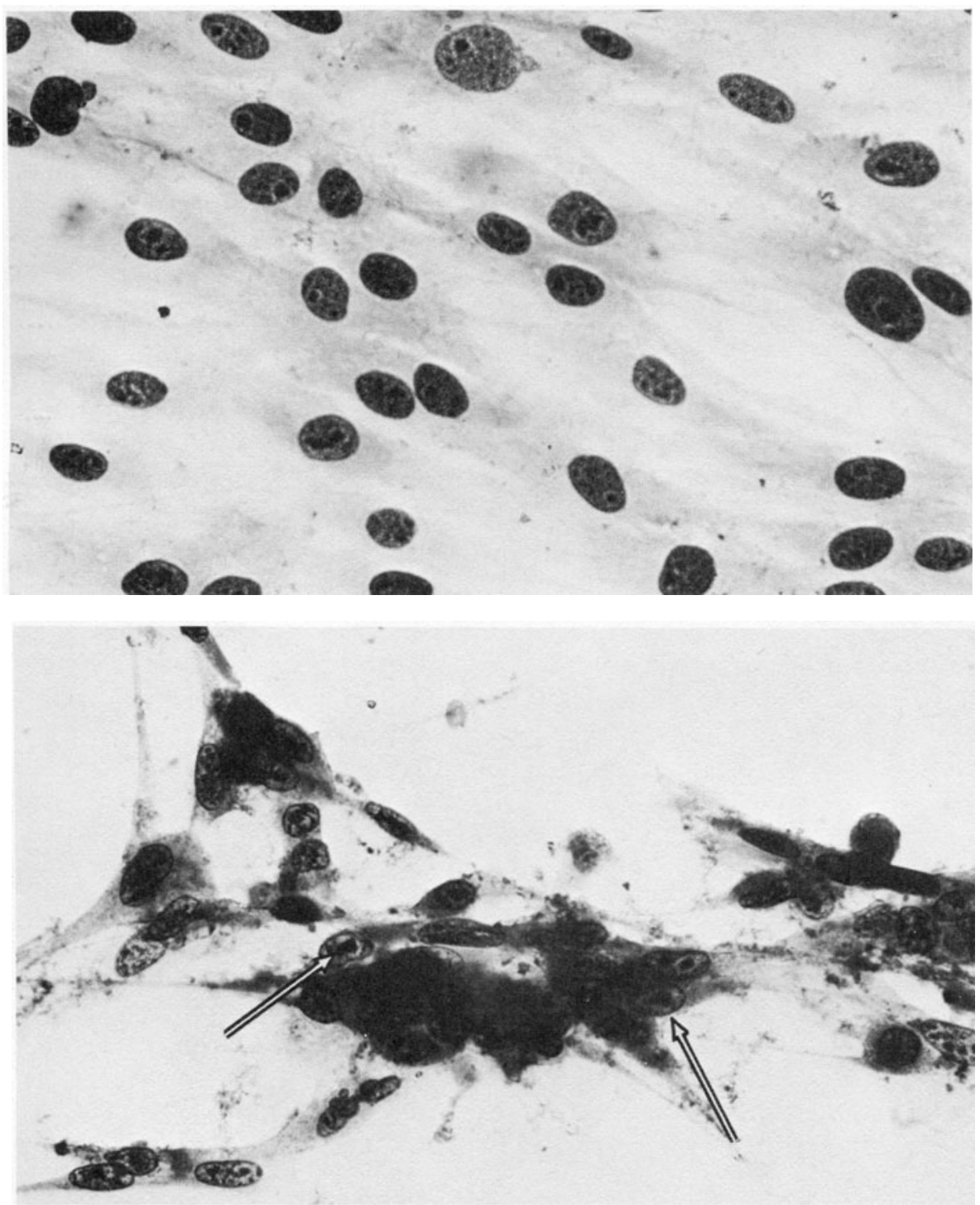

FIGURE 18. RTG-2 cells infected with $H$. salmonis showing marked basophilia, Cowdry Type A intranuclear inclusions, and fusion. Top: Uninoculated control. Bottom: Inoculated. Arrows indicate inclusions. From Wolf et al. (1978). Reprinted with the permission of the American Society of Microbiology.

Atlantic salmon (Salmo salar), brook trout (Salvelinus fontinalis), brown trout (Salmo trutta), and yearling O. nerka were refractory. In light of the Japanese virus NeVTA and its origin, it is noteworthy that $\mathrm{H}$. salmonis could not be recovered from the American O. nerka specimens at termination of the work. After injection of virus, the first deaths occurred among rainbow trout at 25-33 days, and the disease course continued for 
several weeks. Virus was recoverable by direct inoculation of cell cultures with filtrates from infected tissues. Interestingly enough, transmission did not ensue when young susceptible trout were kept with moribund and dead victims of the infection.

Herpesvirus salmonis was apparently isolated in several different years from captive brood stock at a single hatchery. The brood stock was eventually disposed of, and the virus has not appeared again. Morevoer, virological examinations, during a 2-year period, of fish in all facilities in the contiguous states that received fertile eggs from the source hatchery yielded no incidence of $H$. salmonis. Such a single source for a fish virus has not been previously recognized. Failure of the virus to be transported with eggs from infected females might be due to elution during incubation, to the use of iodophores as egg disinfectants, and possibly also to the presence of temperatures at recipient facilities that were higher than tolerated by the virus. It is also conceivable that failure to show fish-to-fish transmission experimentally involves as yet unknown environmental factors.

It is perhaps somewhat academic to discuss control measures for $H$. salmonis infections, because there is now no way of knowing whether the virus caused or even contributed to the mortality of the adult rainbow trout from which the virus was isolated. Because yearling rainbow trout were refractory, extrapolation suggests that adults would also be refractory.

The peculiar low-temperature response of $H$. salmonis indicates that if an epizootic were to occur, elevation of the water temperature to $18^{\circ} \mathrm{C}$, or whatever the fish could tolerate above $15^{\circ} \mathrm{C}$, could greatly reduce losses from the virus.

Uncertainty as to whether the Japanese isolant NeVTA is the same as $H$. salmonis dictates that similarities and differences of the two agents be compared.

The NeVTA agent has an average diameter of $80 \mathrm{~nm}$, and enveloped forms average $230 \mathrm{~nm}$. Maximum titer in RTG-2 cells is $10^{4.5} \mathrm{TCID}_{50}$ / $\mathrm{ml}$, and infectivity during storage at $4^{\circ} \mathrm{C}$ was completely lost at 6 months. Other features of the virus were not described by Sano (1976). Cell cultures stained with hematoxylin and eosin showed syncytia and spherical eosinophilic inclusions in the cytoplasm, but neither nuclear inclusions nor margination of chromatin was mentioned. The greatest differences occur in histopathological changes; however, it must be remembered that two different host species are involved. In $O$. nerka having a natural infection, there is granular degeneration of skeletal muscle, leakage of proteinaceous material into Bowman's capsule, and vacuolation of pancreatic acinar cells - none of which was found in rainbow trout experimentally infected with $H$. salmonis. Both species, however, showed swelling and loss of gill epithelium. Whereas syncytia were found in the pancreas of fish infected by $H$. salmonis, Sano (1976) found syncytia in renal interstitial cells. 
Further investigation will be required to resolve the question of identity of the two viruses.

\section{Carp Pox Herpesvirus (Herpesvirus epithelioma)}

The common carp (Cyprinus carpio) is a freshwater cyprinid originally native to China, where for millenia it was propagated for food and ornament. The carp was introduced to Europe during the 13th century and has since been widely grown as a food fish. The United States imported carp during the late 1800s, it being the expectation (which was never realized) that the New World, too, would regard carp highly as a food fish. Instead, the carp in America is generally disdained; it has adapted to feral life in a wide range of waters and is considered by most to be a coarse or trash fish.

In Europe, the condition known as carp pox or epithelioma papulosum has been recognized and described since the Middle Ages; in Western literature, it is the oldest known disease condition of fish. In the absence of recognized parasites and microbial pathogens, the etiology was uncertain, but the possibility of viral etiology was broached at the turn of the century when Lowenthal (1907) reported intranuclear inclusions and related them in inclusions of viral diseases then recognized. Subsequently, other workers postulated a viral etiology, but it remained for Schubert (1964) to provide the first concrete evidence in the form of micrographs of indisputable virions.

Carp pox is a benign, nodular, transiently chronic hyperplasia of epithelium usually occurring in multiple foci on skin and fins and occasionally on eyes and gills. The lesions are adequately vascularized so that they do not become necrotic. They do not occur internally; neither do they metastasize. Their appearance is smooth, waxy to glassy, and variously pigmented (Fig. 19). Most often, their color is similar to that of background skin, at times with a pinkish hue from vascularization. The lesions are up to several centimeters in diameter and one to several millimeters thick.

The effect of carp pox on the host is usually considered to be negligible, but some observers have attributed a slight retardation of growth to presence of the condition. The behavior of affected fish is normal, but when the lesions slough, pigmented scars follow, and in Europe, marketability of the product declines.

Histologically, the lesions consist of epidermal cells in the usual moderately stratified layers, but in places the cells are elongate and radiate outward to form papillae of highly proliferated cells. Mitoses are common, and the speed of proliferation often results in mucous cells occurring at some depth between papillae, literally being overgrown. Some of the neoplastic cells bear intranuclear inclusions, but that aspect is not universally present. 


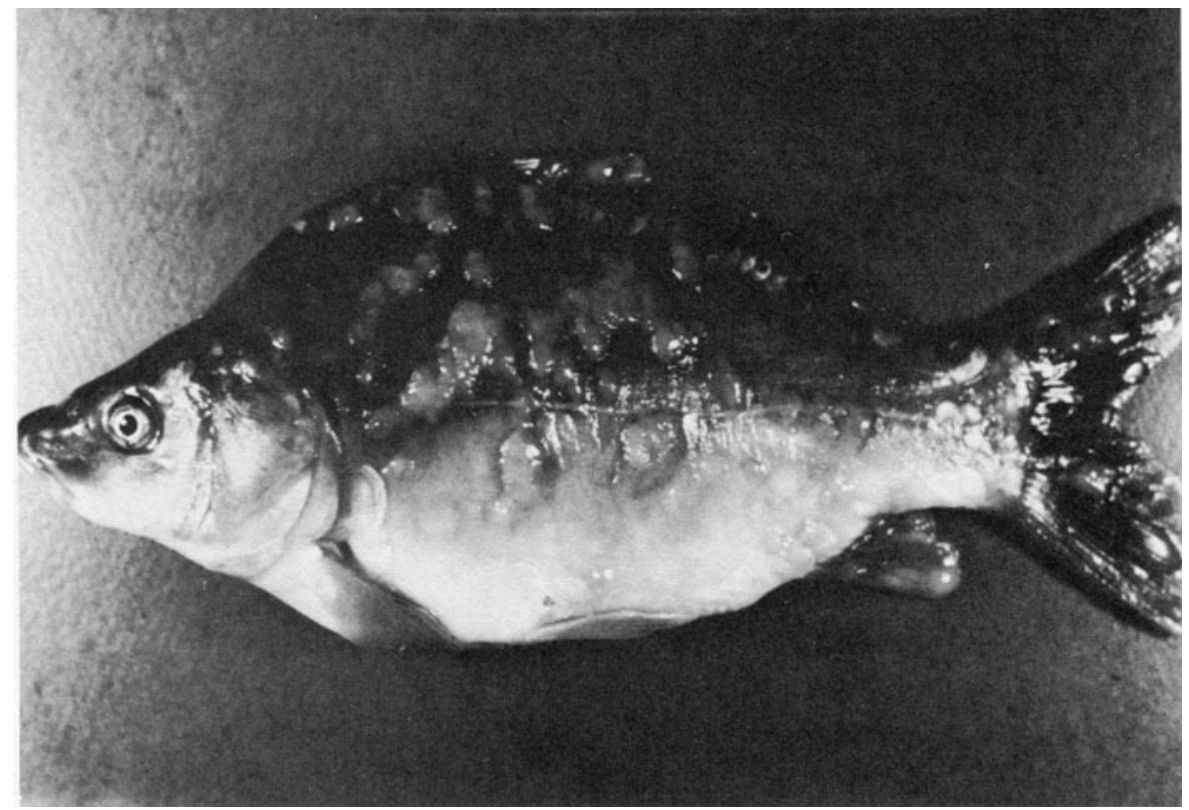

FIGURE 19. Common carp with multiple dermal lesions of "carp pox," circumstantially attributed to a herpesvirus. Courtesy of N.N. Fijan. From Wolf (1973). Reprinted with the permission of Academic Press.

Schubert $(1964,1966)$ published many illustrations of the virus, but only his 1964 report gives virion dimensions. Nuclear particles measured about $110 \mathrm{~nm}$ and polymorphic nucleoids about $50 \mathrm{~nm}$. Enveloped virions $(140-150 \mathrm{~nm})$ were found only in cytoplasm.

Sonstegard and Sonstegard (1978) reported substantial breakthroughs in carp pox. The apparent enigma of why carp pox had not been found in the United States was explained when they reported its presence in the Laurentian Great Lakes. The disease had been here, but had not been recognized. More important, they described transmission by cohabitation or by the application of lesion material to abraded skin. In carp held at $10^{\circ} \mathrm{C}, 2$ months' incubation was required. Hybrids of carp and goldfish (Carassius auratus) were susceptible, but the goldfish itself was refractory. The Sonstegards attempted to isolate the herpesvirus, using five different fish cell lines. No transformation was observed in $\mathrm{BB}$ (ictalurid), BF-2 (centrarchid), RTG-2 (salmonid), or FHM and CAR (cyprinid) cells. Failure to detect change in the cyprinid cell lines is particularly interesting; though the FHM is epithelial, the CAR is fibroblastic but of goldfish origin.

Carp pox has been clinically and histologically diagnosed in other cyprinids and even in fish of other families. Now that experimental transmission of the infection has been described, the matter of host range needs 
to be more accurately established. Alternatively, additional electron microscopy of lesions from other species of fish could be enlightening.

\section{Channel Catfish Herpesvirus (Channel Catfish Virus)}

The channel catfish (Ictalurus punctatus) is a member of the family Ictaluridae and native to North America, where it occurs widely in the warmer temperate latitudes. This esteemed food fish has been introduced elsewhere in the world because it grows rapidly and is well adapted to aquaculture. Over 45 million $\mathrm{kg}$ are raised annually in the United States, the greatest weight of any fish cultured in America.

Farm-raised channel catfish were the source of the first herpesvirus to be isolated from a fish. Relevant reviews of the catfish herpesvirus were given in reports by McCraren (1972), Wolf (1973), and Plumb (1977).

During the 1960s, the farm propagation of channel catfish underwent a marked expansion, and with it an intensification of its husbandry. As could well be expected, health problems were aggravated; notable among them were epizootics involving young-of-the-year that ran an acute course and resulted in high mortality. Fijan (1968) isolated an agent that has been unequivocally characterized as a herpesvirus and shown to be the etiological agent of the epizootics. Channel catfish virus $(\mathrm{CCV})$ is available from the American Type Culture Collection as VR-665.

Under natural conditions, CCV causes a peracute hemorrhagic and systemic infection only among fry and fingerling $I$. punctatus. Incubation time can be as short as $72 \mathrm{hr}$. Blue catfish (I. furcatus) and walking catfish (Clarias batrachus, a close relative of the ictalurids) can be infected by injection. The degree of host specificity of CCV is exceptionally high.

CCV disease has a sudden onset and typically occurs at summer temperatures of $25^{\circ} \mathrm{C}$ or higher, particularly following stress of handling or low dissolved-oxygen levels. Victim fish show distress and move to pond margins. Many affected fish are lethargic, but some show a terminal agonal and convulsive spiral swimming. Food is refused.

Externally, victim fry are exophthalmic, and abdomens are distended. Hemorrhages are common along the ventral side, under the mouth, and in the base of fins, and surround a distended vent. Gills are pale and often hemorrhagic.

Internally, the digestive tract contains no food, kidneys are pale and enlarged, and the body cavity contains a pale yellow, sometimes reddish, fluid. Liver and spleen may be pale and enlarged, and viscera in general may show petechiation or hemorrhages.

Histopathological changes have been described in experimentally infected fish by Wolf et al. (1972) and in both naturally infected and experimentally infected fish by Major et al. (1975). Plumb et al. (1974) reported on both light and electron microscopy of tissues of experimentally 
infected specimens. Key features of the disease are hemorrhage, edema, and marked necrosis of kidneys, liver, and digestive tract. As in many fish viral diseases, the kidneys are particularly vulnerable. Hematopoietic and excretory tissues are edematous and show necrosis (Fig. 20). Infiltration of renal hematopoietic tissue occurs within a few hours after infection, and tubules show damage within $18 \mathrm{hr}$. Coincident with peak virus titer, kidney changes are severe by $96 \mathrm{hr}$. Liver shows necrosis, vascular congestion, hemorrhage, and obvious but regional edema (Fig. 21). In some cases, hepatocytes have eosinophilic cytoplasmic inclusions. Histopathological changes in liver occur later than in kidneys, and virus titers peak about a day later. The digestive tract has focal areas of macrophage concentration and shows evidence of edema. The mucosa and submucosa of some victims are necrotic and may slough into the lumen. Consistent with hemorrhages seen externally, extravasation of blood is found between muscle bundles.

CCV has been well characterized. Wolf and Darlington (1971) described many of the in vitro properties of the agent. Numerous studies of various biological features and host-pathogen relationships have been carried out during the past decade, the most relevant of which were cited

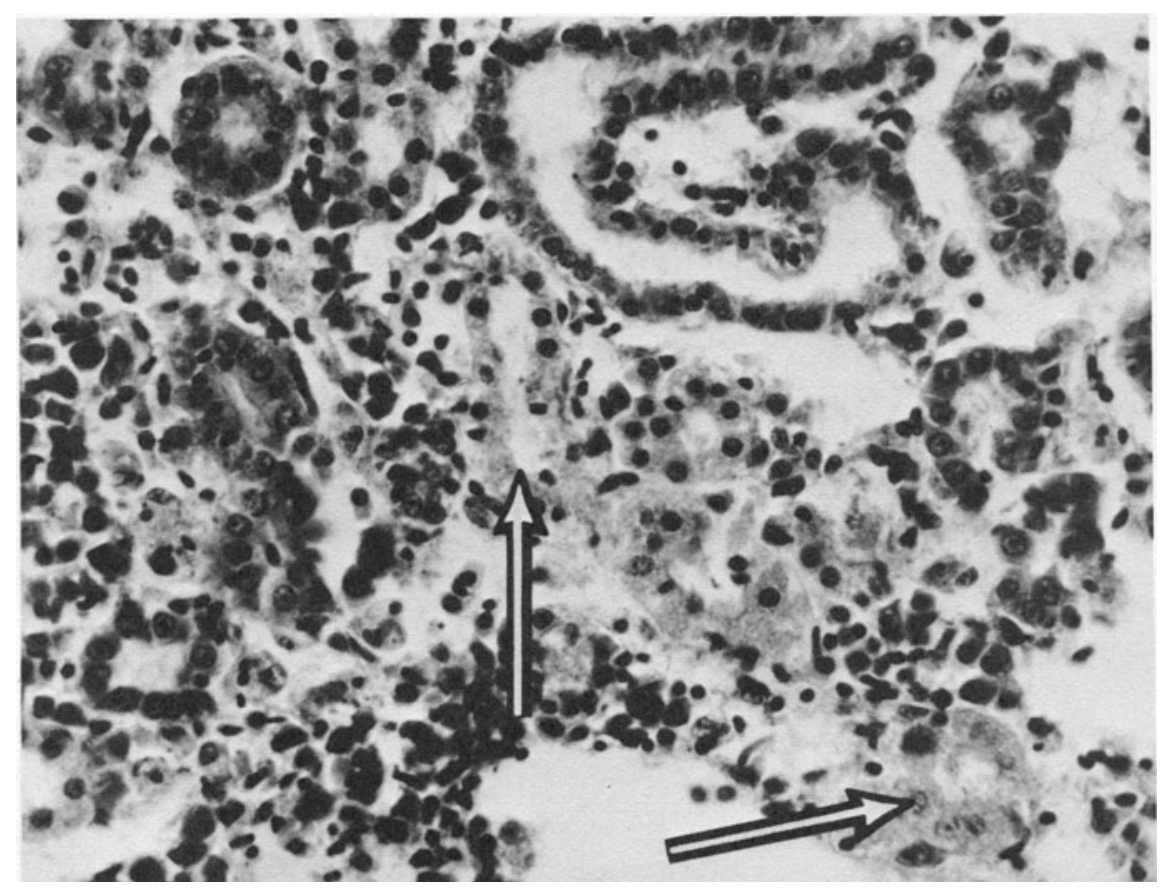

FIGURE 20. Channel catfish kidney showing generalized edema and tubule necrosis (arrows) resulting from experimental infection with CCV. Hematoxylin-eosin. From Wolf et al. (1972). Reprinted with the permission of the Journal of the Fisheries Research Board of Canada. 


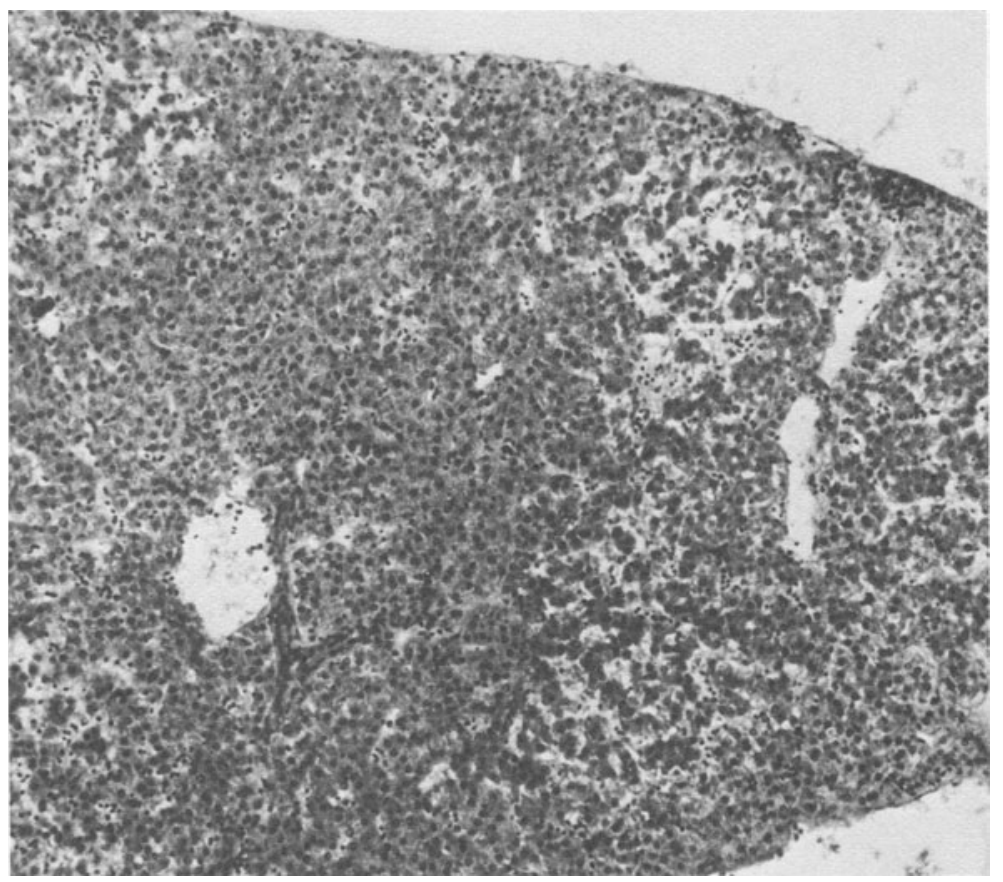

FIGURE 21. Channel catfish liver with regional edema, vascular congestion, and areas of necrosis following experimental infection with CCV. Hematoxylin-eosin.

by Plumb (1977). Goodheart and Plummer (1975) were the first to determine the G + C content, and Chousterman et al. (1979) confirmed the molecular weight and used restriction endonucleases to map the nucleotide sequences of the viral DNA. Thus far, CCV is the most extensively and intensively studied herpesvirus of a lower vertebrate.

The size of the CCV capsid is about $100 \mathrm{~nm}$, and the nucleoid 40$50 \mathrm{~nm}$ (Fig. 22). Capsomere number is 162, and negatively stained enveloped forms measure $175-200 \mathrm{~nm}$ (Fig. 23). Buoyant density in $\mathrm{CsCl}$ is $1.715 \mathrm{~g} / \mathrm{cm}^{3}$, corresponding to a $\mathrm{G}+\mathrm{C}$ value of $56 \%$ (Goodheart and Plummer, 1975). The molecular weight of the DNA genome is $86 \times 10^{6}$. Terminal ends of the molecule consist of a redundant sequence of $12 \times 10^{6}$ (Chousterman et al., 1979).

When CCV is dried on concrete, glass, or netting, infectivity does not persist longer than $48 \mathrm{hr}$. Virus survives in pond water at $25^{\circ} \mathrm{C}$ no longer than 2 days, and is inactivated even more rapidly when in contact with pond soil. Infectivity is readily preserved by freezing in culture medium containing serum, but the $\mathrm{pH}$ should be in the physiological range; stability is greater at -80 than at $-20^{\circ} \mathrm{C}$. Infectivity in carcasses persists for several months at $-20^{\circ} \mathrm{C}$, but longer storage at that temperature is not recommended. The common practice of freezing and thawing tissue to yield virus degrades CCV. Three freeze-thaw cycles are each accom- 


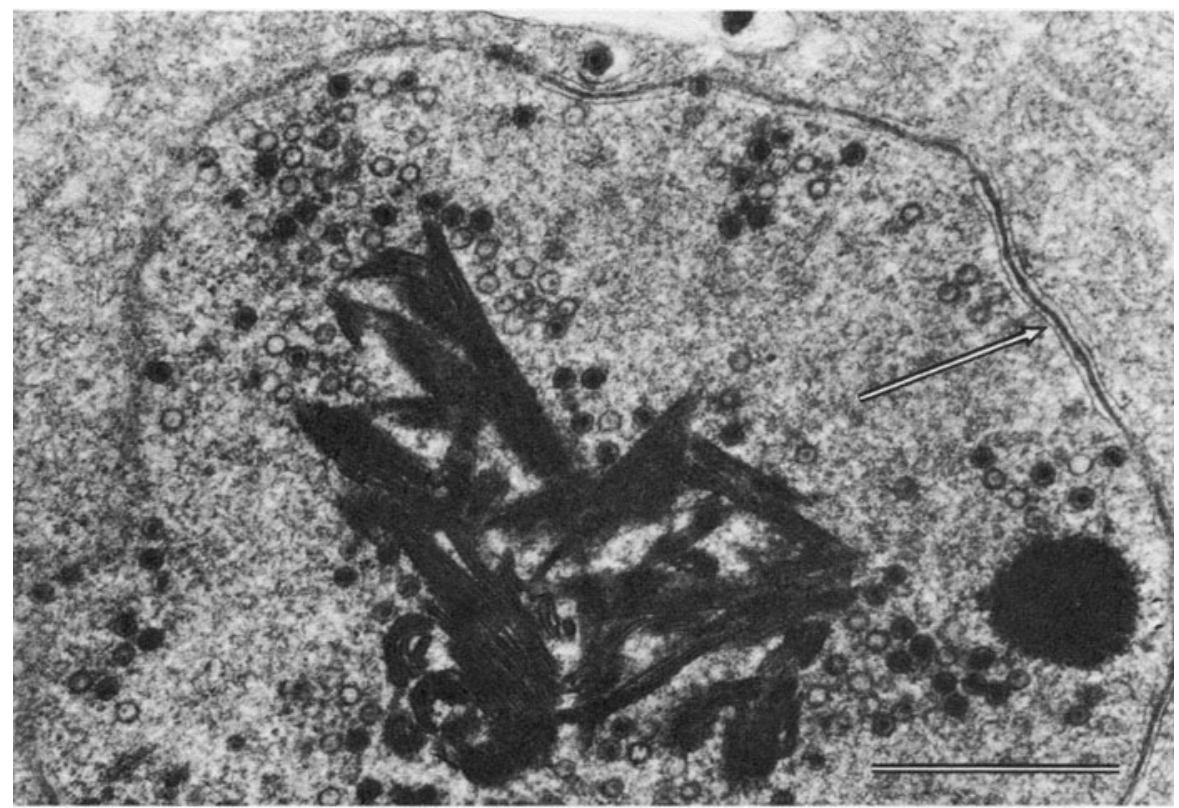

FIGURE 22. BB cell $10 \mathrm{hr}$ after infection with CCV. Empty and full capsids occur in the nucleus together with electron-dense lamellar or fibrillar structures. In places, the nuclear membrane has been disrupted (lower left), and in others it has been reduplicated (arrow). Scale bar: $1 \mu \mathrm{m}$. From Wolf and Darlington (1971). Reprinted with the permission of the American Society of Microbiology.

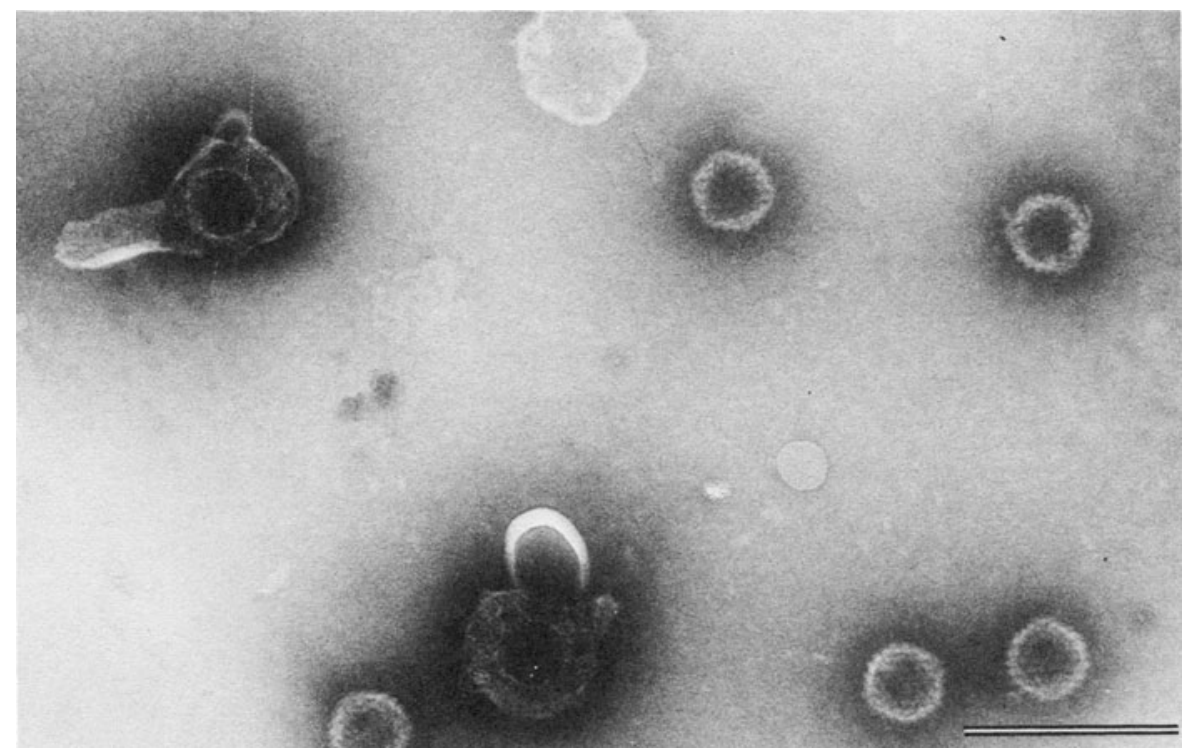

FIGURE 23. Negatively stained CCV particles. Scale bar: $0.25 \mu \mathrm{m}$. From Wolf and Darlington (1971). Reprinted with the permission of the Amrican Society of Microbiology. 
panied by a decline in titer, and at the final assay, only $20 \%$ of the original infectivity remains.

Representative mammalian, avian, amphibian, and fish cell lines have been tested, but CCV has been replicated only by ictalurid and clariid fish cell lines. Most work has been done with the ictalurid lines BB and CCO (Bowser and Plumb, 1980). Temperature range for replication extends from 10 to $33^{\circ} \mathrm{C}$, but yields are generally poor at $10-16^{\circ} \mathrm{C}$ (Fig. 24). Optimal growth occurs at $25-30^{\circ} \mathrm{C}$, at which maximal yield is about $10^{7}$ $\mathrm{PFU} / \mathrm{ml}$ (Figs. 25 and 26). At $33^{\circ} \mathrm{C}$, a one-step growth curve peaks at about $12 \mathrm{hr}$, but that temperature is higher than tolerated for sustained growth of the BB cell line. Regardless of temperature, the amounts of released virus and cell-associated virus are equal.

In vitro, CCV first causes cells to round somewhat and then induces syncytia and, ultimately, necrosis (Figs. 27 and 28). Polykaryocytes can become massive, but they ultimately undergo contraction and a terminal lysis ensues (Fig. 29). Stained cell cultures show a generalized basophilia, and classic Cowdry Type A intranuclear inclusions (Fig. 30). Electron microscopy of infected cells, whether in culture or in diseased tissues, shows the classic sequence of viral replication. Virions are first found as naked capsids in the nucleus and as enveloped forms in the cytoplasm or extracellulary. A noteworthy finding is the presence of large masses of electron-dense lamellae in the nucleus of infected cells (see Fig. 22). The masses of lamellae are variously postulated to be paramyelin or precursors to capsomeres or capsids.

Identification of CCV is most commonly accomplished with serum neutralization tests, but fluorescent-antibody techniques have also been used (Bowser, 1976).

Fish-to-fish transmission of CCV is readily demonstrated by holding susceptibles with fish undergoing an active infection or in effluent from

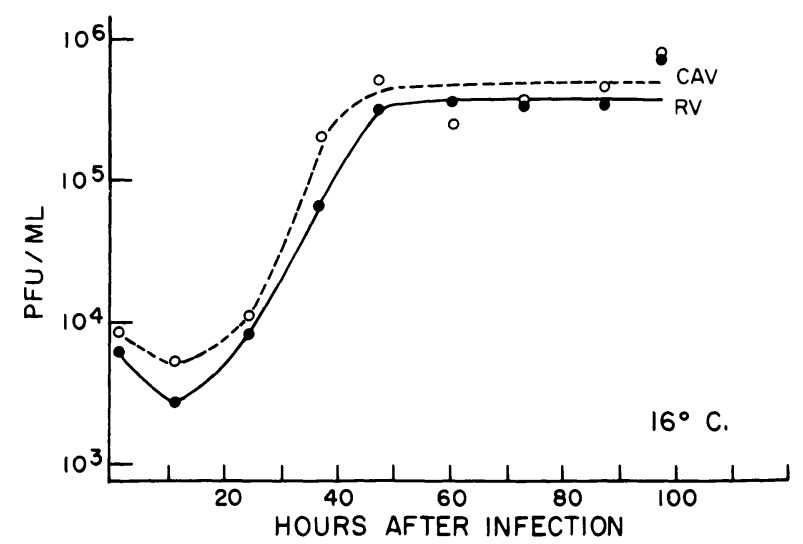

FIGURE 24. Representative growth curve of CCV in BB cells at $16^{\circ} \mathrm{C}$ in which virus yield exceeds input by a factor of only about 50 . (RV) Released virus; (CAV) cell-associated virus. From Wolf (1973). Reprinted with the permission of Academic Press. 


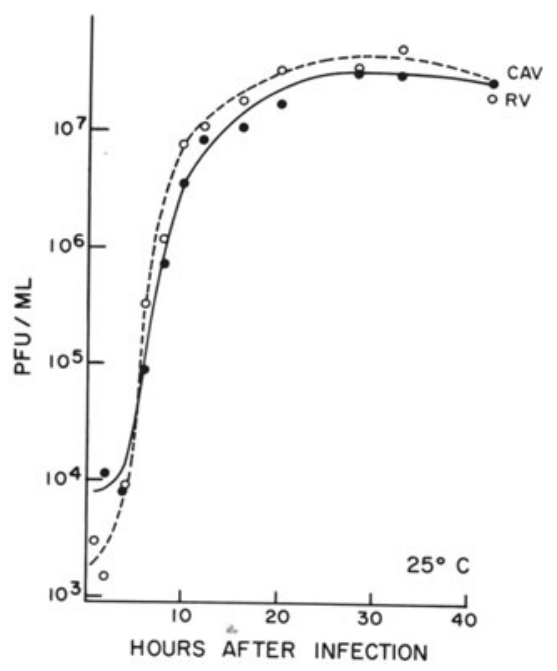

FIGURE 25. Representative growth curve of CCV in BB cells at optimal temperature of $25^{\circ} \mathrm{C}$ in which virus yield is several thousand times greater than input. (RV) Released virus; (CAV) cell-associated virus. From Wolf (1973). Reprinted with the permission of Academic Press.

them. Experimental infections are commonly initiated by intramuscular or intraperitoneal injection, by feeding, or by brushing infective material on the gills. Simple immersion in a viral suspension is also effective and has the advantage of being the most natural and least traumatic.

A wealth of circumstantial evidence has been accumulated in support of vertical transmission; it is the means that best explains the regular occurrence of $\mathrm{CCV}$ in the progeny of certain populations of captive brood

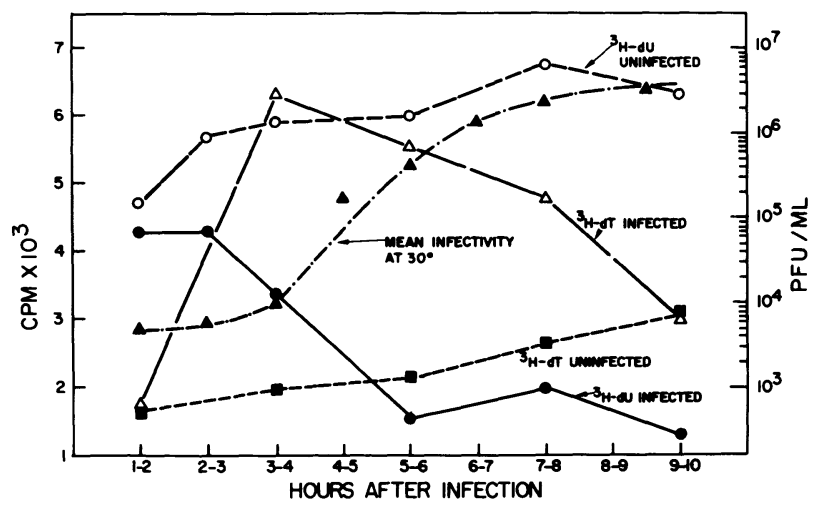

FIGURE 26. A comparison of $\left[{ }^{3} \mathrm{H}\right]$ deoxyuridine $\left({ }^{3} \mathrm{H}-\mathrm{dU}\right)$ and $\left({ }^{3} \mathrm{H}\right]$ deoxythymidine $\left({ }^{3} \mathrm{H}-\mathrm{dT}\right)$ uptake at $30^{\circ} \mathrm{C}$ by infected and uninfected $\mathrm{BB}$ cells. An average one-step growth curve is included for reference purposes. From Wolf (1973). Reprinted with the permission of Academic Press. 


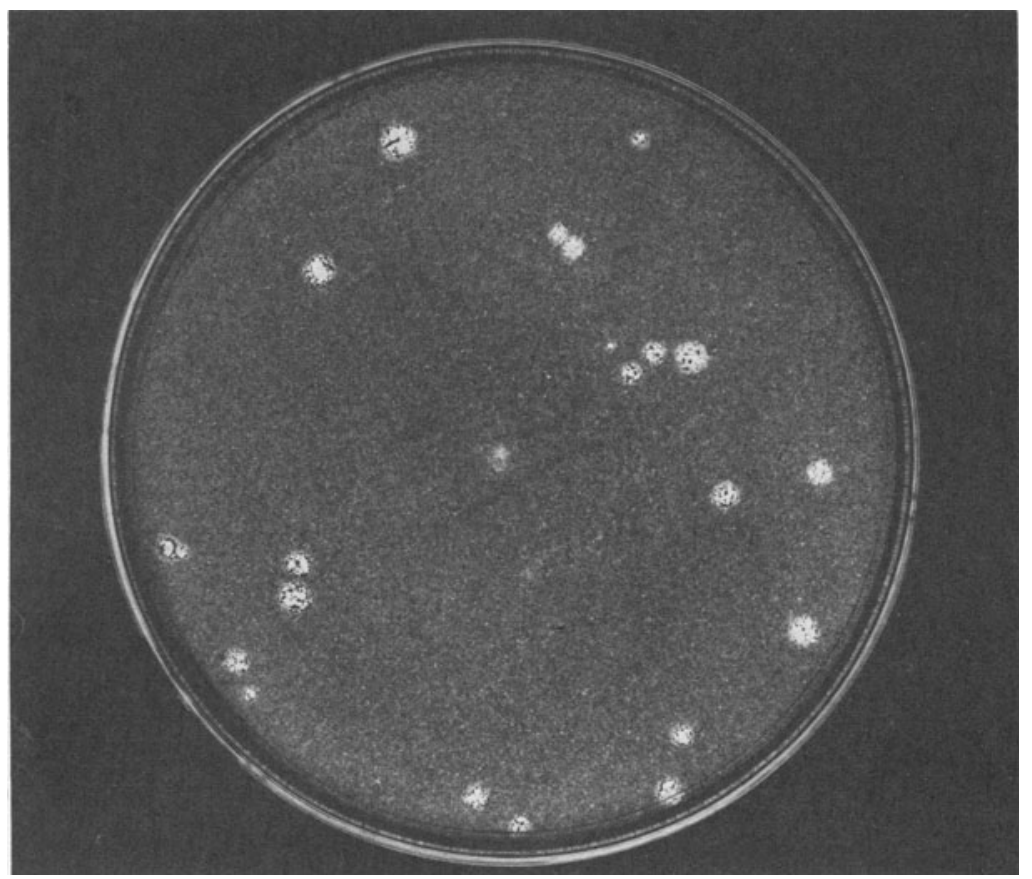

FIGURE 27. CCV plaques on BB cells consisting, in gross appearance, of peripheral syncytia around central areas of necrosis.

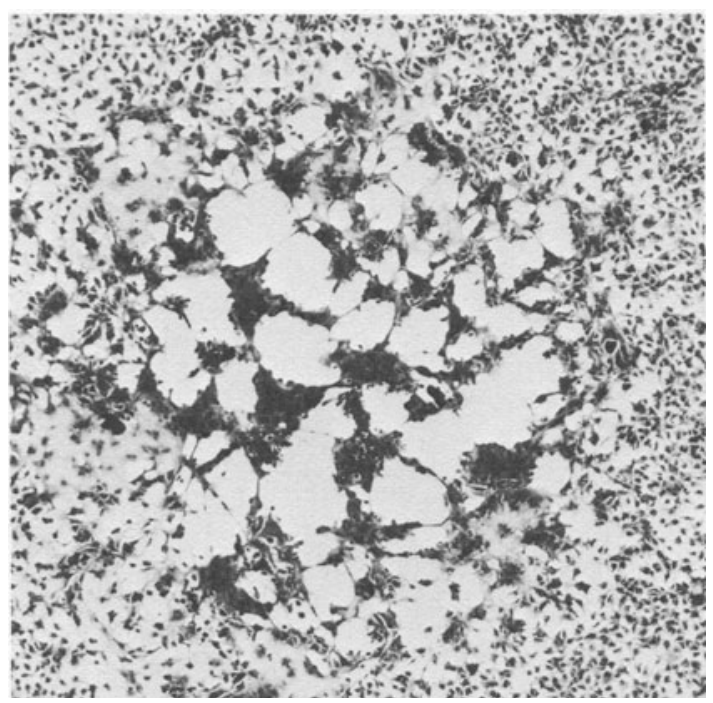

FIGURE 28. Close-up of CCV plaque in BB cells showing peripheral pyknosis and areas of fused cells. The plaque center shows advanced contraction and necrosis. From Wolf and Darlington (1971). Reprinted with the permission of the American Society of Microbiology. 


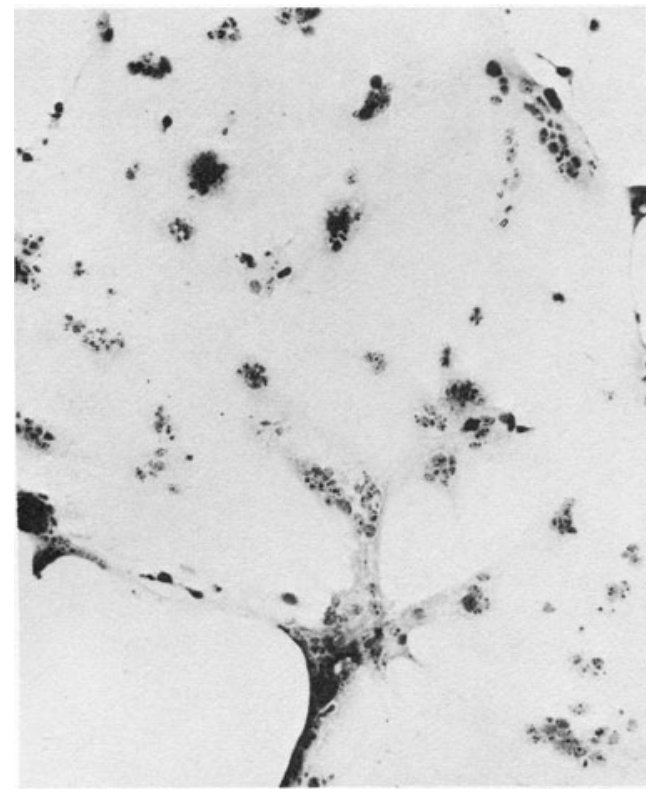

FIGURE 29. Large syncytium in BB cell culture induced by CCV. From Wolf and Darlington (1971). Reprinted with the permission of the American Society of Microbiology.

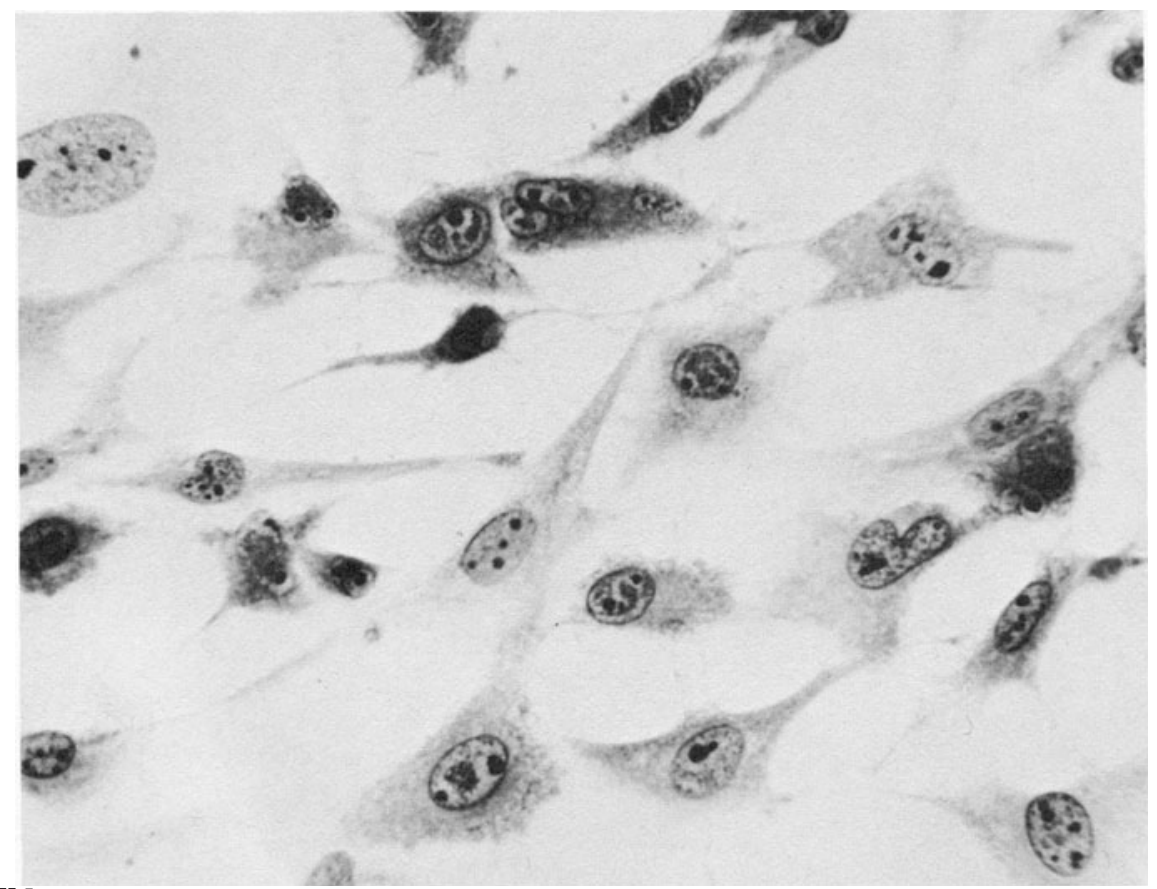

FIGURE 30. Margination of chromatin and Cowdry Type A intranuclear inclusions caused by CCV in BB cells. From Wolf (1973). Reprinted with the permission of Academic Press. 
stock. However, the numerous attempts to isolate, or otherwise even to demonstrate, the virus in adult fish have thus far failed. No method of isolation, direct culture of tissues, or cocultivation has been productive. Notably lacking have been efforts to culture neural tissue or to induce the release of CCV by temperature or hormonal manipulation. It seems certain that adults must harbor the virus and that its release is related to the seasonal reproduction cycle or temperature change or both.

Indirect evidence supports the postulated source of CCV. Plumb (1977) assayed sera of 71 adults from a population with a history of progeny with CCV. By conventional standards, 67 (94\%) showed a neutralization index equal to or greater than $1.6 ; 2$ were equivocal and 2 were negative. Sera of 10 adults from a population with a clean health history were without CCV-neutralizing activity.

It is interesting to note that CCV can be rather easily isolated from the victims of an outbreak. The incubation time can be as short as 72 $\mathrm{hr}$, and the epizootic may last but 7-10 days. Thereafter, for all practical purposes, it has not been possible to make an isolation. Field observations of CCV survivors have shown that the fish were unthrifty and did not fare as well as uninfected fish. That phenomenon was subsequently demonstrated experimentally. Although surviving fish fed well and lacked histological evidence of viral lesions, their weight averaged only $15 \%$ of that attained by the uninfected. The results are a tantalizing link in the hypothesis that the adult is the source of CCV.

The immune response of channel catfish to live CCV has been studied by several investigators, but the work of Heartwell (1975) was the most extensive. Such research typically involved fish that were older than 1 year, thus providing a host that would survive and would yield serum samples of adequate volume for study. Initial viral inoculation did not cause disease, but it did induce a humoral response that varied considerably from fish to fish but generally peaked at about 9 weeks at $22-28^{\circ} \mathrm{C}$ and then declined. A second injection evoked a weak and short-lived anamnestic reaction at about 10 days. Heat-killed virus apparently was not antigenic. Heartwell (1975), who also studied the viral-neutralizing component of the immune serum, characterized it as a macroglobulin with a molecular weight of $8-9 \times 10^{5}$ daltons, somewhat heat-labile, and subject to some reduction with 2-mercaptoethanol and $2 \mathrm{M}$ urea. Complete reduction occurred with $6 \mathrm{M}$ urea.

The first line of practical defense against CCV consists of avoidance-bypassing any source of stock that has a history of the disease. Second, if an epizootic occurs, the affected population can be destroyed and the ponds disinfected. Lability of CCV is rather marked, and in the absence of susceptible fish the virus is rapidly inactivated. Precautionary disinfection with $20-50$ ppm chlorine is advised, to be followed by bioassay with susceptible fish in a holding cage.

Plumb and coworkers (Plumb, 1973a,b; Plumb and Gaines, 1975) have addressed problems associated with CCV. They found that reduction 
of temperature from 28 to $19^{\circ} \mathrm{C}$ markedly reduced losses when an epizootic occurs. He admitted, however, that under the common extensive aquaculture of catfish, temperature modulation may be difficult or impractical. Where CCV cannot be avoided, e.g., under conditions where well water is not available and a contaminated water source must be used, Plumb et al. (1975) found that several strains of catfish have significant degrees of resistance and that others are markedly susceptible. Under the test conditions employed, survival was only $30 \%$ in the Falcon strain, but nearly $90 \%$ in the Yazoo strain. In addition, hybrids of the Yazoo strain and strains with moderate resistance also had satisfactory levels of resistance.

Several workers have used antiviral drugs in in vivo or in vitro work with CCV, but practical chemical control measures have not been developed. As an example, Koment and Haines (1978), who compared herpes simplex and CCV, found that CCV required 20 times more phosphonacetic acid to inhibit its replication.

Attenuation of CCV has been achieved by passing CCV repeatedly in a cell line from the walking catfish. Early results indicate that protection against virulent virus is provided, but it is not known whether the attenuated strain is stable and will not revert to a virulent form.

\section{E. Turbot Herpesvirus (Herpesvirus scophthalmi)}

The turbot (Scophthalmus maximus) is a European species of marine flatfish of the family Bothidae (lefteye flounders). The turbot is highly regarded as a food fish, and considerable effort is being spent to rear the fish in commercial husbandry. When significant mortality occurred among cultured fry, a search for a possible cause revealed a herpesvirus in association with brachial and dermal polykaryocytes or giant cells (Fig. 31). The agent has not yet been isolated, nor have transmission studies been carried out. The size and shape of the agent leave little doubt about its grouping, and the original investigators have proposed the working name Herpesvirus scophthalmi (Buchanan et al., 1978).

The agent came to light when heavy mortality (about $30 \%$ during fall and winter) occurred among fry being reared in heated effluent from a nuclear generating plant in Scotland. Search for an etiological agent failed to implicate bacteria or parasites. The fry were anorexic and lethargic and offered little resistance when netted. When they were in contact with tank bottoms, the head and tail were elevated abnormally. Externally and internally, the gross physical appearance of the fry was normal, but the polykaryocytes were abundantly evident in histological sections of skin and gills; other organs and tissues were without abnormalities (Richards and Buchanan, 1978).

Polykaryocytes apparently arose from the Malpighian layer, and commonly were $45-75 \mu \mathrm{m}$ in diameter, though some were as large as 130 $\mu \mathrm{m}$ in greatest dimension (Fig. 32). The usual giant cell had only one 


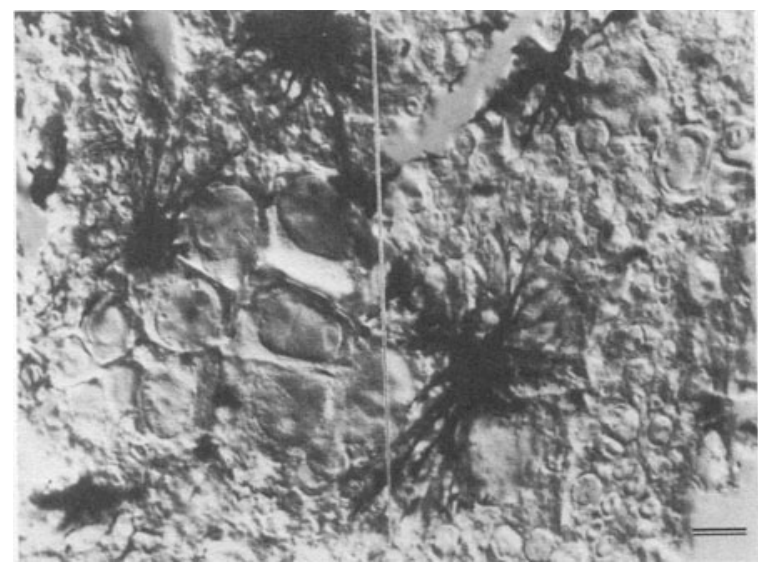

FIGURE 31. Differential interference phase-contrast micrograph of giant cells in skin of an infected turbot. Black dendritic forms are melanophores. Scale bar: $50 \mu \mathrm{m}$. From Buchanan et al. (1978). Reprinted with the permission of the British Veterinary Association.

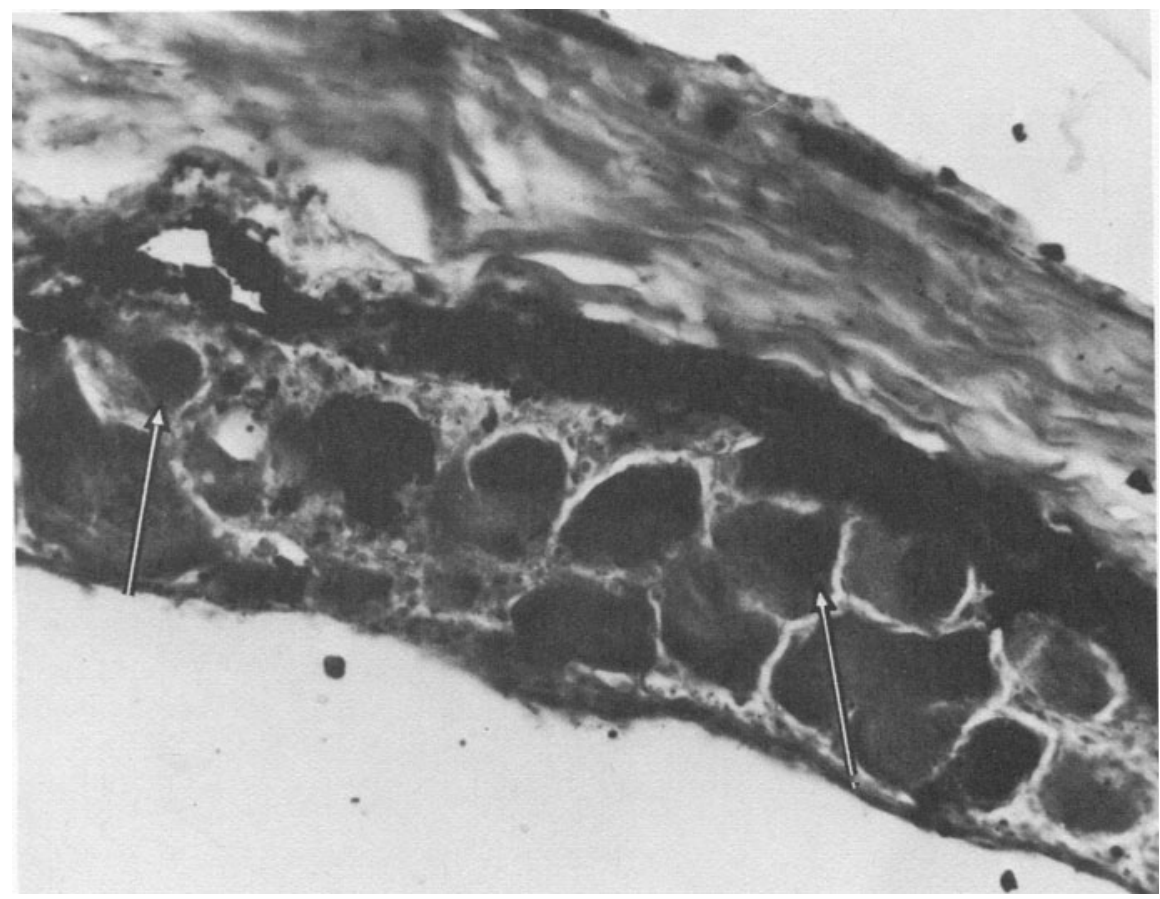

FIGURE 32. Section of skin from infected turbot showing prominent giant cells. Size and shape of nuclei (arrows) vary. Hematoxylin-eosin. $\times 200$. Courtesy of J.S. Buchanan. 
nucleus that occupied as much as $90 \%$ of the cell. A few cells had several nuclei, presumably destined to fuse. Giant-cell nuclei were often fenestrated and showed a basophilic Feulgen-positive, periodic acid-Schiff (PAS)-negative area. The nucleus also showed coarse Feulgen-positive granules. Cytoplasm was generally basophilic, but coarse PAS-negative and Feulgen-positive granules were present (Richards and Buchanan, 1978).

Heavy infection of gills resulted in hyperplasia and fusion of lamellae with attendant vascular stasis, fibrinous thrombosis, and reduction of functional respiratory exchange area (Fig. 33).

Buchanan and Madeley (1978) elegantly described and illustrated ultrastructural details of infected cells and H. scophthalmi. Naked capsids, some empty and some with a nucleoid, occur in the nucleus (Fig. 34), at times in paracrystalline array. Virion size is about $100 \mathrm{~nm}$. Enveloped particles measure 200-220 nm and occur in the cytoplasm (Fig. 35). The envelope is trilaminar and shows an outer fringe of petal-like spikes about $18 \mathrm{~nm}$ long, much like those of a coronavirus (Fig. 36).

The occurrence of giant cells in the turbot is not peculiar to fish in

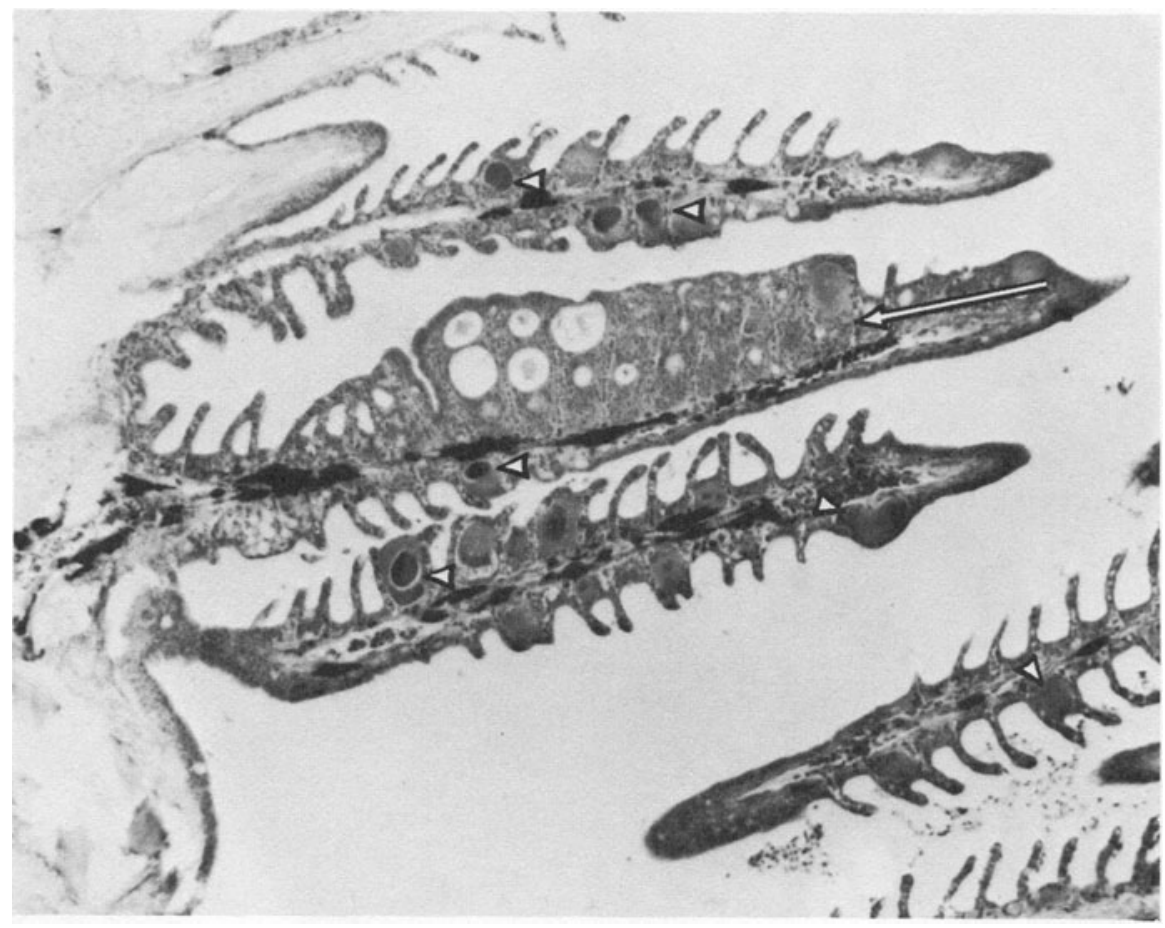

FIGURE 33. Gill section of infected turbot showing giant cells (points) and hyperplasia resulting in fusion of lamellae and reduction of respiratory surface (arrow). Hematoxylineosin. $\times 130$. From Richards and Buchanan (1978). Reprinted with the permission of Blackwell Scientific Publications Ltd. 


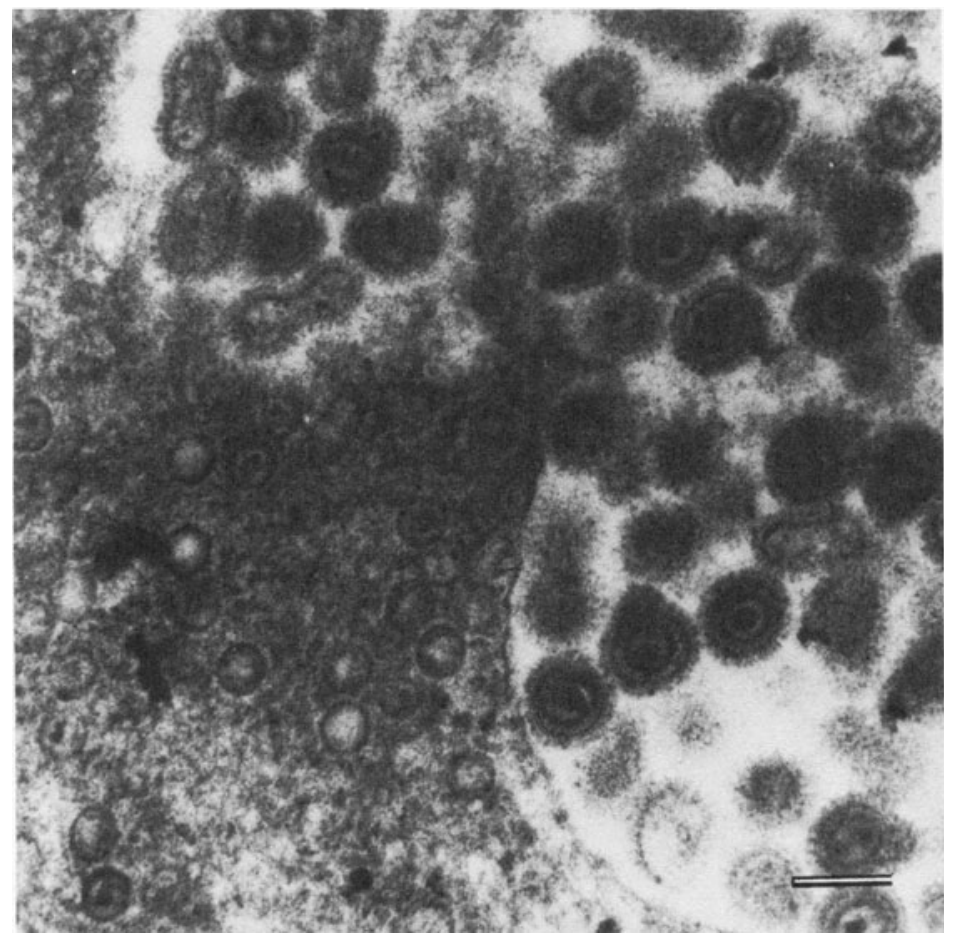

FIGURE 34. Thin section of infected turbot cell showing empty and full 100-nm capsids in the nucleus (left) and enveloped particles in the cytoplasm. Scale bar: $100 \mathrm{~nm}$. From Buchanan et al. (1978). Reprinted with the permission of the British Veterinary Association.

FIGURE 35. Negatively stained turbot herpesvirus particles. Scale bar: $100 \mathrm{~nm}$. From Buchanan et al. (1978). Reprinted with the permission of the British Veterinary Association.

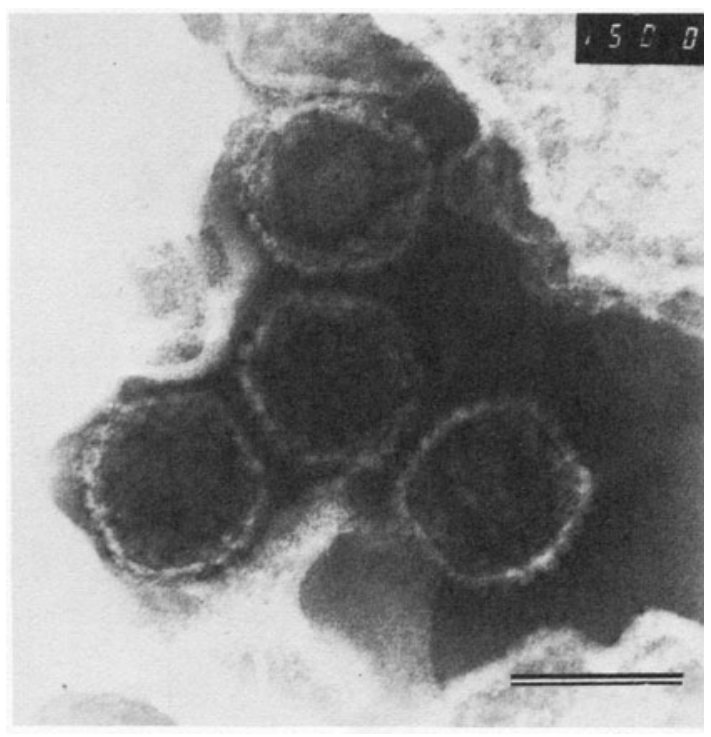




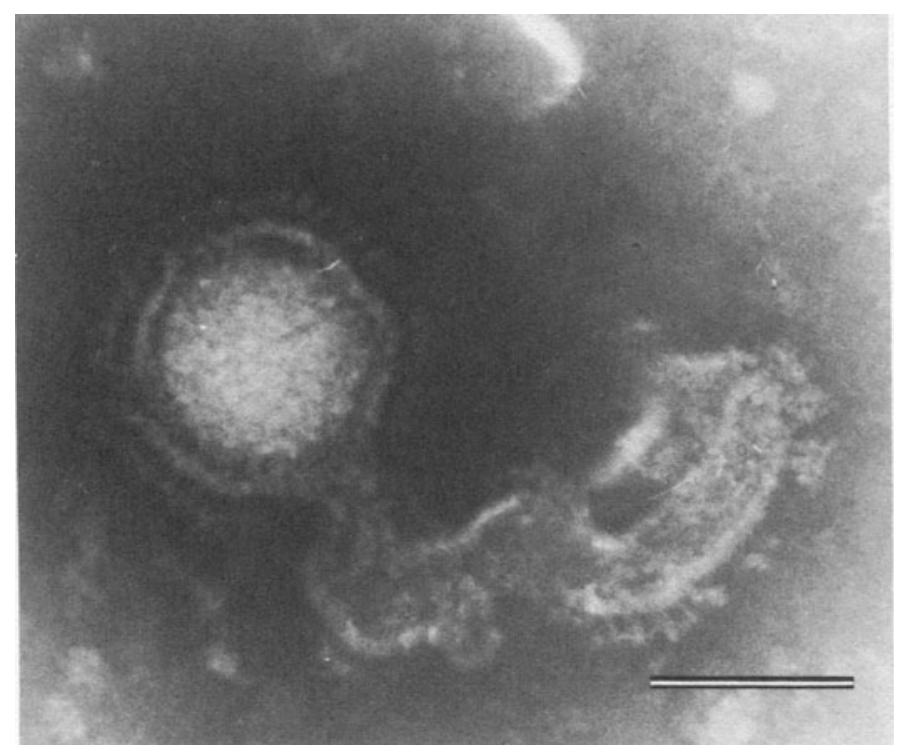

FIGURE 36. Negatively stained turbot herpesvirus particle showing fringe of 18-nm spikes. Scale bar: $100 \mathrm{~nm}$. From Buchanan et al. (1978). Reprinted with the permission of the British Veterinary Association.

husbandry; they have also been found in otherwise normal fish taken directly from the wild. Also, hatchery fish normal in behavior and appearance were found with pathognomonic cells, although they were fewer than in clinically afflicted fish. Perhaps the virus plays a causal role in the mortality, and abnormal stress may also be involved. Typically, mortality has followed (within a matter of days) handling, transport, temperature fluctuations, or high chlorine levels.

\section{F. Walleye Herpesvirus}

The walleye (Stizostedion vitreum) is a percid highly regarded by anglers as choice table fare. Ecologically, walleyes are considered to be coolwater creatures and thus are found in fresh waters of the central and northern tiers of the United States and well into the Canadian Provinces.

Walleyes have long been known to harbor viruses. Walker (1969) noted that among walleyes of the New York region, at least three different viruses could be distinguished by electron microscopy - the large (200$\mathrm{nm}$ ) icosahedral cytoplasmic particles of lymphocystis disease, 100-nm intercellular virions associated with a dermal sarcoma, and abundant 80$\mathrm{nm}$ virions budding from membranes of cells constituting a third and histologically distinctive condition known as epidermal hyperplasia. The particles associated with the two neoplasms have not yet been isolated. 
Lymphocystis virus has been isolated from freshwater and marine fishes and presumably could be readily isolated from walleyes.

Kelly et al. (1980a) isolated a new herpeslike virus from a single adult walleye afflicted with epidermal hyperplasia. The source location was a lake in Saskatchewan. The lesions were present on fish taken in early spring, but regressed rapidly thereafter and were never observed later in the year (Kelly et al., 1980b). Some specimens were tagged and recaptured a year later; accordingly, the authors concluded that the virus probably did not contribute significantly to postspawning mortality.

Details of histopathological findings have not been reported, but electron microscopy of thin-sectioned hyperplastic epidermis showed numerous incomplete virions present within cell nuclei. Size was not reported, but infectivity was said to pass through membranes with a mean pore diameter of $200 \mathrm{~nm}$, but not $100 \mathrm{~nm}$.

Data supporting the herpesvirus nature of the agent are inhibition of in vitro replication by IUdR and 5-bromodeoxyuridine (BUdR); inhibition by BUdR is reversed in the presence of excess thymidine. More to the point, replication was inhibited by $10^{-3} \mathrm{M}$ phosphonacetate. The original isolation was made on the WO line of walleye ovary cells, but other cell lines of walleye origin, WC-1 and WC-2, were also susceptible. As would be expected for a herpesvirus, the walleye agent was not replicated in RTG-2 or CHSE-214 (salmonid), BB (ictalurid), or FHM (cyprinid) cell lines, which are collectively able to support most other isolated fish viruses.

The walleye herpesvirus is ether-labile, and in vitro it induces the formation of syncytia followed by lysis. Replication occurs at 4 and $15^{\circ} \mathrm{C}$, but (consistent with the cool water preference of its host) not at $20^{\circ} \mathrm{C}$. Plaquing is routinely carried out on the WC- 1 cell line; at $15^{\circ} \mathrm{C}$, plaques are produced in 10-13 days. Maximal titer is $10^{5} \mathrm{PFU} / \mathrm{ml}$.

Kelly et al. (1980b) noted that electron microscopy of infected cell cultures showed particles identical to the virus seen in the original lesion. The relationship of the virus to the induction of neoplasms is as yet undetermined, but the authors correctly speculated that the agent should be regarded as possibly being a cause of mortality in the young. Such a pattern of virulence for the young and association with skin neoplasms occurs with the Oncorhynchus masou virus (OMV) in Japan.

\section{REFERENCES}

Bowser, P.R., 1976, Fluorescent and antibody test for channel catfish virus, Fish Health News 5:4.

Bowser, P.R., and Plumb, J.A., 1980, Channel catfish virus: Comparative replication and sensitivity of cell lines from channel catfish ovary and the brown bullhead, $J$. Wildl. Dis. 16:451.

Buchanan, J.S., and Madeley, C.R., 1978, Studies on Herpesvirus scophthalmi infection of turbot Scophthalmus maximus (L.) Ultrastructural observations, J. Fish Dis. 1:283. 
Buchanan, J.S., Richards, R.H., Sommerville, C., and Madeley, C.R., 1978, A herpes-type virus from turbot (Scophthalmus maximus L.), Vet. Rec. 102:527.

Chousterman, S., Lacasa, M., and Sheldrick, P., 1979, Physical map of the channel catfish virus genome: Location of sites for restriction endonucleases Eco RI, Hind III, Hpa I, and $X b a$ I, J. Virol. 31:73.

Clark, H.F., and Karzon, D.T., 1972, Iguana virus, a herpes-like virus isolated from cultured cells of a lizard, Iguana iguana, Infect. Immun. 5:559.

Clark, H.F., and Lunger, P.D., 1981, Viruses of reptiles, in: Diseases of Reptilia (J.E. Cooper and D.F. Jackson, eds.), pp. 135-164, Academic Press, New York.

Cox, W.R., Rapley, W.A., and Barker, I.K., 1980, Herpesvirus-like infection in a painted turtle (Chrysemys picta), J. Wildl. Dis. 16:445.

Fijan, N., 1968, Progress report on acute mortality of channel catfish caused by a virus, Off. Int. Epizoot. Bull. 69:1167.

Frye, F.L., Oshiro, L.O., Dutra, F.R., and Carney, J.D., 1977, Herpesvirus-like infection in two Pacific pond turtles, J. Am. Vet. Med. Assoc. 171:882.

Goodheart, C.R., and Plummer, G., 1975, The densities of herpesviral DNAs, Prog. Med. Virol. 19:324.

Haines, H., 1978, A herpesvirus disease of green sea turtles in aquaculture, Mar. Fish Rev. Paper 1294:33.

Haines, H., and Kleese, W.C., 1977, Effect of water temperature on a herpesvirus infection of sea turtles, Infect. Immun. 15:756.

Heartwell, C.M., 1975, Immune response and antibody characterization of the channel catfish (Ictalurus punctatus) to a naturally pathogenic bacterium and virus, U.S. Fish Wildl. Serv. Tech. Paper 85, 34 pp.

Kelly, R.K., Nielsen, O., and Yamamoto, T., 1980a, A new herpes-like virus (HLV) of fish (Stizostedion vitreum vitreum), In Vitro 16:255.

Kelly, R.K., Nielsen, O., Campbell, J.S., and Yamamoto, T., 1980b, Current status of lymphocystis, dermal sarcoma/fibroma, and related diseases in walleye, Stizostedion vitreum vitreum, in western Canada, in: Proceedings of the Fourth Biennial Fish Health Section and Fish Disease Workshops, Seattle, Washington (mimeographed).

Kimura, T., Yoshimizu, M., Tanaka, M., and Sannohe, H., 1981a, Studies on a new virus (OMV) from Oncorhynchus masou. I. Characteristics and pathogenicity, Fish Pathol. 15:143-147.

Kimura, T., Yoshimizu, M., and Tanaka, M., 1981b, Studies on a new virus (OMV) from Oncorhynchus masou. II. Oncogenic nature, Fish Pathol. 15:149-153.

Kimura, T., Yoshimizu, M., and Tanaka, M., 1981c, Fish viruses: Tumor induction in Oncorhynchus keta by the herpesvirus, in: Phyletic Approach to Cancer (C.J. Dawe, J.C. Harshbarger, T. Sugimura, S. Takayama, and S. Kodo, eds.), pp. 59-68, Japan Sci. Soc. Press, Tokyo.

Koment, R.W., and Haines, H.G., 1977, A new reptilian herpesvirus isolated from the green sea turtle, Chelonia mydas, Abstr. Annu. Meet. Am. Soc. Microbiol. New Orleans, Louisiana, May 8-13, p. 347.

Koment, R.W., and Haines, H., 1978, Decreased antiviral effect of phosphonacetic acid on the poikilothermic herpesvirus of channel catfish disease, Proc. Soc. Exp. Biol. Med. 159:21.

Lowenthal, W., 1907, Einschlussartige Zell und Kernveränderungen in der Karpfenpocke, Z. Krebsforsch. 5:197.

Lunger, P.D., and Clark, H.F., 1978, Reptilia-related viruses, in: Advances in Virus Research (M.A. Lauffer, K. Maramorosch, F.B. Bang, and K.M. Smith, eds.), pp. 159-204, Academic Press, New York.

Major, R.D., McCraren, J.P., and Smith, C.E., 1975, Histopathological changes in channel catfish (Ictalurus punctatus) experimentally and naturally infected with channel catfish virus disease, J. Fish. Res. Board Can. 32:563.

McCraren, J.P., 1972, Channel catfish virus disease (CCVD): A current review, Proc. Annu. Conf. Western Assoc. Game Fish Comm. 52:528. 
Monroe, J.H., Shibley, G.P., Schidlovsky, G., Nakai, T., Howatson, A.F., Wivel, N.W., and O'Conner, T.E., 1968, Action of snake venom on Rauscher virus, I. Natl. Cancer Inst. 40: 135 .

Padgett, F., and Levine, A.S., 1966, Fine structure of the Rauscher leukemia virus as revealed by incubation in snake venom, Virology 30:623.

Plumb, J.A., 1973a, Effects of temperature on mortality of fingerling channel catfish (ICtalurus punctatus) experimentally infected with channel catfish virus, I. Fish. Res. Board Can. 30:568.

Plumb, J.A., 1973b, Neutralization of channel catfish virus by serum of channel catfish, $I$. Wildl. Dis. 9:324.

Plumb, J.A., 1977, Channel catfish virus disease, U.S. Fish Wildl. Serv. Fish Dis. Leaflet 52, $8 \mathrm{pp}$.

Plumb, J.A., and Gaines, J.L., Ir., 1975, Channel catfish virus disease, in: Pathology of Fishes (W.E. Ribelin and G. Migaki, eds.), pp. 287-302, University of Wisconsin Press, Madison.

Plumb, J.A., Gaines, J.L., Mora, E.C., and Bradley, G.G., 1974, Histopathology and electron microscopy of channel catfish virus in infected channel catfish, Ictalurus punctatus (Rafinesque), J. Fish Biol. 6:661.

Plumb, J.A., Green, O.L., Smithermann, R.O., and Pardue, G.B., 1975, Channel catfish virus experiments with different strains of channel catfish, Trans. Am. Fish. Soc. 104:140.

Raynaud, A., and Adrian, M., 1976, Lésions cutanées á structure papillomateuse associées á des virus chez le lézard vert (Lacerta virdis Laur.), C. R. Acad. Sci. Ser. D 283:845.

Rebell, G., Rywlin, A., and Haines, H., 1975, A herpesvirus-type agent associated with skin lesions of green sea turtles in aquaculture, Am. J. Vet. Res. 36: 1221.

Richards, R.H., and Buchanan, J.S., 1978, Studies on Herpesvirus scophthalmi infection of turbot Scophthalmus maximus (L.): Histopathological observations, J. Fish Dis. 1:3.

Sano, T., 1976, Viral diseases of cultured fishes in Japan, Fish Pathol. 10:221.

Schubert, G., 1964, Elektronenmikroskopische Untersuchungen zur Pockenkrankheit des Karpfens, Z. Naturforsch. 19:675.

Schubert, G.H., 1966, The infective agent in carp pox, Off. Int. Epizoot. Bull. 65:1011.

Simpson, C.F., Jacobson, E.R., and Gaskin, J.M., 1979, Herpesvirus-like infection of the venom gland of Siamese cobras, J. Am. Vet. Med. Assoc. 175:941.

Sonstegard, R.A., and Sonstegard, K.S., 1978, Herpesvirus-associated epidermal hyperplasia in fish (carp), in: Proceedings of the International Symposium on Oncogenesis and Herpesviruses III (G. De-Thé, W. Henle, and F. Rapp, eds.), pp. 863-868, International Agency for Research on Cancer, Scientific Publication No. 24, Lyon, France.

Walker, R., 1969, Virus associated with epidermal hyperplasia in fish, Natl. Cancer Inst. Monogr. 31:195.

Wolf, K., 1973, Herpesviruses of lower vertebrates, in: The Herpesviruses (A.S. Kaplan, ed.), pp. 495-520, Academic Press, New York.

Wolf, K., 1979, Comparative pathogenesis and virulence of poikilotherm vertebrate herpesviruses, in: Proceedings of the 4th Munich Symposium on Microbiology on Mechanisms of Viral Pathogenesis and Virulence (P.A. Bachmann, ed.), pp. 183-200, WHO Collaborating Centre for Collection and Evaluation of Data on Comparative Virology.

Wolf, K., and Darlington, R.W., 1971, Channel catfish virus: A new herpesvirus of ictalurid fish, J.Virol. 8:525.

Wolf, K., and Mann, J.A., 1980, Poikilotherm vertebrate cell lines and viruses: A current listing for fishes, In Vitro 16:179.

Wolf, K., and Smith, C.E., 1981, Herpesvirus salmonis: Pathological changes in parenterally infected rainbow trout fry, J. Fish Dis., 445-457.

Wolf, K., Herman, R.L., and Carlson, C.P., 1972, Fish viruses: Histopathologic changes associated with experimental channel catfish virus disease, I. Fish. Res. Board Can. 29:149.

Wolf, K., Sano, T., and Kimura, T., 1975, Herpesvirus disease of salmonids, U.S. Fish Wildl. Serv. Fish Dis. Leaflet 44, 8 pp. 
Wolf, K., Darlington, R.W., Taylor, W.G., Quimby, M.C., and Nagabayashi, T., 1978, Herpesvirus salmonis: Characterization of a new pathogen of rainbow trout, J. Virol. 27:659.

Zeigel, R.F., and Clark, H.F., 1972, Electron microscopy observations on a new herpes-type virus isolated from Iguana iguana and propagated in reptilian cells in vitro, Infect. Immun. 5:570. 